\title{
Circulating MicroRNAs as Biomarkers in Biliary Tract Cancers
}

\author{
Pablo Letelier ${ }^{1,+}$, Ismael Riquelme ${ }^{2,3,+}$, Alfonso H. Hernández ${ }^{1}$, Neftalí Guzmán ${ }^{1}$, \\ Jorge G. Farías ${ }^{4}$ and Juan Carlos Roa ${ }^{5, *}$ \\ 1 School of Health Sciences, Universidad Católica de Temuco, Manuel Montt 56, 4813302 Temuco, Chile; \\ pletelier@uct.cl (P.L.); alfonso.hernandez@uct.cl (A.H.H.); nguzman@uct.cl (N.G.) \\ 2 Molecular Pathology Laboratory, Department of Pathological Anatomy, School of Medicine, \\ Universidad de La Frontera, Avenida Alemania 0458, 3rd Floor, 4810296 Temuco, Chile; \\ ismael.riquelme.contreras@gmail.com \\ 3 Scientific and Technological Bioresource Nucleus (BIOREN), Universidad de La \\ Frontera, Avenida Francisco Salazar 01145, Casilla, 54-D Temuco, Chile \\ 4 Department of Chemical Engineering, Faculty of Engineering and Sciences, Universidad de La Frontera, \\ 54-D Temuco, Chile; jorge.farias@ufrontera.cl \\ 5 Department of Pathology, Centre for Investigational Oncology (CITO), Advanced Centre for Chronic \\ Diseases (ACCDiS), Pontificia Universidad Católica de Chile, Marcoleta 377, 7rd Floor, \\ 8330024 Santiago, Chile \\ * Correspondence: jcroa@med.puc.cl; Tel.: +56-998-847-9697 \\ + These authors contributed equally to this work.
}

Academic Editor: William Chi-shing Cho

Received: 31 March 2016; Accepted: 10 May 2016; Published: 23 May 2016

\begin{abstract}
Biliary tract cancers (BTCs) are a group of highly aggressive malignant tumors with a poor prognosis. The current diagnosis is based mainly on imaging and intraoperative exploration due to brush cytology havinga low sensitivity and the standard markers, such as carcinoembryonic antigen (CEA) and carbohydrate 19-9 (CA19-9), not having enough sensitivity nor specificity to be used in a differential diagnosis and early stage detection. Thus, better non-invasive methods that can distinguish between normal and pathological tissue are needed. MicroRNAs (miRNAs) are small, single-stranded non-coding RNA molecules of $~ 20-22$ nucleotides that regulate relevant physiological mechanisms and can also be involved in carcinogenesis. Recent studies have demonstrated that miRNAs are detectable in multiple body fluids, showing great stability, either free or trapped in circulating microvesicles, such as exosomes. miRNAs are ideal biomarkers that may be used in screening and prognosis in biliary tract cancers, aiding also in the clinical decisions at different stages of cancer treatment. This review highlights the progress in the analysis of circulating miRNAs in serum, plasma and bile as potential diagnostic and prognostic markers of BTCs.
\end{abstract}

Keywords: biliary tract cancers; microRNAs; biomarkers

\section{Introduction}

Biliary tract cancers (BTCs) are a group of highly aggressive malignant tumors with a poor prognosis; therefore, most patients are diagnosed at an advanced stage when the tumor is unresectable or metastatic [1,2]. In recent years, new strategies have been sought for the early diagnosis of BTCs, with the most studied being biochemical markers that have proven most relevant in complementing diagnosis and prognosis: total bilirubin, alanine aminotransferase and tumor markers [3,4]. Serum levels of carcinoembryonic antigen (CEA) and carbohydrate 19-9 (CA19-9) are usually elevated and serve as a standard for clinical diagnosis, although none has sufficient sensitivity or specificity to be used in a differential diagnosis and early stage detection $[5,6]$. In view of these 
limitations, diagnosis occurs by pathological examination of the biopsy obtained either via endoscopic retrograde cholangiopancreatography (ERCP), or percutaneous transhepatic cholangiography (PTC), or ultimately, during surgical exploration [7]. Thus, better non-invasive methods that can distinguish between normal and pathological tissue are needed. MicroRNAs (miRNAs) are small non-coding RNA molecules of $\sim 20-22$ nucleotides, which play an important regulatory role in the mRNA silencing of genes [8] involved in carcinogenic processes, such as development [9], cell cycle and apoptosis [10-12], directly affecting tumor progression [13]. For this reason, miRNAs are promising therapeutic targets and diagnostic biomarkers [14]. A biomarker is a biological indicator that should be stable in fluids, accessible, disease-specific [15] and easy-to-measure in the body in order to predict the incidence of outcome or disease [16]. Many studies have shown that miRNAs are a novel class of biomarkers to diagnose human cancers $[17,18]$. The analysis and determination of circulating miRNAs in multiples biological fluids, such as serum, urine, saliva and bile, could be an alternative to the determination of proteins $[19,20]$. Recently, accumulated evidence has shown a detectable and deregulated expression of tissues and circulating miRNAs in BTCs, closely associated with prognosis and diagnosis in these patients [21-24]. This review focuses on a general description of bile tract cancers, the biogenesis of miRNAs and their regulatory mechanisms and the progress of circulating miRNAs as diagnosis and prognosis biomarkers for BTCs.

\section{Brief Description of Biliary Tract Cancers}

Biliary tract cancers include intra- and extra-hepatic cholangiocarcinoma (CCA), ampullary carcinoma (AC) and gallbladder cancer (GBC) [25,26]. Many risk factors are strongly associated with BTCs, such as gallstones, chronic inflammation, parasitic infections, biliary duct cysts, hepatolithiasis, primary sclerosing cholangitis (PSC), chronic liver disease, gallbladder polyps, in addition to non-modifiable risk factors, such as ethnic background, increasing age, female gender, congenital biliary abnormalities and genetic factors. Other lifestyle factors, like obesity, multiparity, cigarette smoking, alcohol consumption and hepatitis B or hepatitis $C$ infection, are also strongly related to this pathology [27-29]. Most BTC patients present symptoms similar to those of patients with benign biliary diseases (BBDs) [30]. These neoplasms exhibit dismal long-term survival outcomes, and although these malignancies are anatomically related, each has a distinct molecular biology and clinical and epidemiological presentation [31]. GBC is the most common malignancy of the biliary tract and the fifth most common malignant tumor of the digestive tract. It was first described in 1777 by German surgeon Maximillian Stoll [32,33]. The evolution of this disease is usually asymptomatic, resulting in a late diagnosis with poor survival [32]. The epidemiology of the disease is highly heterogeneous; populations at low risk for GBC are in northern Europe and among the non-Hispanic white population of the United States. The high-risk populations are found in the Andean countries, particularly Chile, Bolivia and among Hispanic and Indian populations in North America with incidence rates of 3.5-7.0 and 10-15 cases per 100,000 habitants in men and women, respectively [34]. CCA is a malignant tumor arising in the bile duct epithelium, usually diagnosed late, when surgery is no longer an option $[35,36]$. Anatomically, CCA is divided into intrahepatic cholangiocarcinoma (iCCA) and extrahepatic cholangiocarcinoma (eCCA), which is divided intoperihilar (pCCA) and distal (dCCA) tumors [37-39]. It was initially described by Durand-Fardel in 1840 [37]. Its frequency is less than $3 \%$ of gastrointestinal malignancies, and its incidence in the U.S. is 1.0/100,000 per year [37]; however, it has a significant impact on public health in Southeast Asian countries (incidence of 96 per 100,000$)$ [40]. AC is a relatively uncommon tumor, representing $0.2 \%-0.5 \%$ of gastrointestinal malignancies; the overall incidence rate is 0.49 per 100,000 individuals in the U.S. [41]. Most ampullary carcinomas are adenocarcinomas [42], and three epithelial types can be found in this area, originating in either the duodenal mucosa, the bile duct or the pancreatic duct [43]. Prognosis depends on histological typing of the tumor and its clinical stage. Studies report a good prognosis if the tumor is limited to the duodenal mucosa without invasion into adjacent organs [43]. The mortality rate of BTCs has increased considerably because of frequent metastasis, high recurrence rates and poor response to chemotherapy 
and radiation therapy when surgical resection is possible. Long-term survival depends heavily on lymph node involvement, negative surgical resection margins and tumor differentiation $[44,45]$. The method for initial study in BTC is abdominal ultrasonography ; however, the sensitivity of this technique to detect early lesions is limited [46]; therefore, most patients are diagnosed at an advanced stage when the tumor is unresectable or metastatic [1,2]. Other high technology, such as computed tomography (CT), cholangioscopy, endoscopic ultrasound (EUS) and magnetic resonance imaging (MRI), are expensive and usually of limited use in the general population, and it is uncommon in the diagnosis of small (early-stage) lesions [47-49].

\section{MicroRNAs Biogenesis and Their Regulatory Mechanisms}

The accumulated evidence indicates that the miRNAs are involved in the regulation of cell differentiation, proliferation and apoptosis [50,51], as well as in the regulation of genes associated with cancer formation [52]. miRNAs may function as tumor suppressors or oncogenes [52-54]. When miRNAs are overexpressed in cancers, they usually function as oncogenes by negatively regulating tumor suppressor genes (pro-apoptotic or anti-proliferative roles). Conversely, when miRNAs are repressed in cancers, they function as tumor suppressor genes and may inhibit cancer cells by regulating oncogenes [55-58].

During biogenesis, miRNAs are initially transcribed by RNA polymerase II or III, as a primary transcripts at the nucleus (pri-miRNA) that contains a stem-loop sequences of $~ 80-n t s$ [59-61]. miRNA genes are located in intergenic regions, intronic regions of known genes, transcribed individually or in tandem with polycistronic sequences $[62,63]$, allowing multiple miRNAs to be expressed simultaneously. This co-expression could ensure negative feedback within the same pathway [64]. A lower number of miRNAs are expressed along with their own promoter regions [65] and regulated by many transcription factors [66]. The pri-miRNA is converted into a $\sim 60-\mathrm{nt}$ precursor or pre-miRNA by nuclease Drosha/DGCR8 [67]. Then, the pre-miRNA is exported from the nucleus into the cytoplasm by exportin 5 (XPO5) and Ran-GTP [68]. This pre-miRNA is then processed to the miRNA/miRNA* duplex in the cytoplasm by its interaction with Dicer ribonuclease and the cofactor TRBP, which finally form the mature miRNA [69]. Finally, one strand is incorporated into the effector RNA induced silencing complex (RISC), which couples this mature sequence to target mRNAs. On the other hand, the passenger strand (miRNA* strand) is degraded by the RISC complex [70-72]. However, in some cases, miRNA* strands are retained, having a regulatory role as a mature miRNA [73]. There are alternative biogenesis pathways that differ in processing steps and the enzymes responsible. Particularly, many miRNAs can be processed by Ago-2 in a Dicer-independent manner [74]. In addition, mirtrons are a type of microRNAs that is located in the intron regions and is digested via the spliceosome [73,75] and/or in a splicing-independent manner, these being so-called "simtrons" [76]. The multiple biogenesis processes could be related to different development stages in cells [76]. Following transcription, miRNAs can be modified at the post-transcriptional level, potentially affecting miRNA stability and the efficiency of miRNA and miRNA* [66].

miRNAs induce gene silencing by binding to target mRNAs in complementary sequences (miRNA recognition element) located in the $3^{\prime}$ untranslated region (UTR) of the mRNA, using a short sequence of approximately 2-8 nucleotides (the seed region) at the $5^{\prime}$ end of the miRNA, allowing miRNA targeting to have more than one mRNA. This interaction inhibits the translation process and protein synthesis, resulting in a complex regulatory network $[12,52,77]$. In addition, some reports indicate that miRNAs can also be joined to the $5^{\prime}$ UTR and the coding region of the mRNAs [78,79]. However, in these regions, the effectiveness in repressing the translation decreases, probably due to the reduced stability in the miRNA-RISC/mRNA complex produced when the ribosomes interact [80]. Furthermore, complex stability depends on the sequence of the binding site, the number of target sites within mRNA, the local structure of RNA and the distance between target sites [81-83].

The mature miRNA attached to the RISC complex is the complex effector of gene silencing, which is presented to enable binding by pairing bases to target sites in the RNA. If there is 
high complementarity between miRNA/mRNA, the mRNA is cleaved by endonuclease Ago2, possibly inclusion bodies and RNA processing (P-bodies) $[77,84]$ and, if imperfectly complementary, only silencing mRNA translation occurs [12,85].

Scientific evidence has shown that miRNAs expression can be controlled by various molecular events, including alterations in genome location, epigenetic changes, transcriptional deregulations and alterations in miRNA biogenesis. Several microRNA genes are located near breakpoint regions, which can present loss of heterozygosity (LOH), amplifications, deletions or mutations [86-88]. Moreover, DNA methylation is a potent regulator of miRNA expression and histone modifications and is a frequent event in cancer [89-91]. Aberrant DNA methylation in the promoter regions produced the silencing of miRNAs, modifying the expression of tumor suppressor miRNAs [92-94] and oncogenic miRNAs $[95,96]$. Moreover Dicer, Drosha and XPO5 inactivation have been shown to induce an altered biogenesis and, therefore, a significant reduction of miRNA levels, leading to an aberrant expression in several cancers [97-101]. Some proteins (HnRNPA1, SMAD1 and SMAD5) have been involved in the regulation of miRNAs precursors, modifying subsequently their expression [102]. A defect in XPO5 also affects the transportation of pre-miRNAs, provoking the nuclear retention of these precursors [66]. Additional evidence has demonstrated that some dietary compounds, such as folate, retinoids and curcumin, modify the microRNAs expression levels, acting as protective factors [103]. Other factors, such as the hormonal status [104] and hypoxic conditions, can also modify miRNA expression [105].

\section{MicroRNAs in Extracellular Vesicles}

One of the most remarkable aspects of miRNAs is their high stability outside the intracellular environment; this aspect is of interest, as potential biomarkers of clinical use (reviewed by Moldovan et al. [106]). The mechanisms by which the circulating miRNAs reach the circulation are not fully understood; however, one of the mechanisms through which they originate is active secretion via extracellular vesicles (EVs) [107]. Extracellular RNAs (exRNA) may exist in essentially four forms: freely circulating, bound to specific proteins, associated with lipoproteins or enclosed in extracellular vesicles (EVs) (Figure 1) [108]. These include exosomes and microvesicles, which are formed by a lipid membrane and contain specific molecules, constituting a communication system between different cell types in physiological and pathological processes $[109,110]$. These EVs have been found in several cell types, including macrophages, endothelial cells, monocytes, leukocytes, tumor cells [111] and even in embryonic stem cells [111]. Exosomes are distributed in various body fluids, including human bile, causing them to come into contact with neighboring or distant cells and then deliver the miRNA content [110,112], exhibiting paracrine effects on tumor growth [113,114].

The molecular structure of an EV is very similar to the parental cell or tissue and may contain other molecules, such as receptors, adhesion molecules, proteins, lipids, growth factors, proteases and exRNAs $[115,116]$. The diversity of exRNA species in EVs is extensive, and according to the different analyses, it is known that miRNA and piwiRNA are the most abundant RNA species, with a lower percentage having been found of pseudo-genes, LncRNAs, tRNAs and mRNAs [117]. miRNAs are secreted both in EVs and in a non-vesicular form. The loading of miRNAs into EVs is controlled by heterogeneous nuclear ribonucleoprotein (hnRNP) A2B1, which recognizes the EXOmotif (GGAG tetranucleotide) of miRNAs (miRNAs into exosomes attached to specific motifs) and regulates the transfer into EVs. Heterogeneous nuclear ribonucleoprotein A2/B1(hnRNPA2B1) inside the EVs is SUMOylated; this post-translational modification is necessary for the loading of miRNAs into EVs [118]. miRNA disposal into the $\mathrm{EV}$ can be facilitated by the addition of non-templated nucleotides to the $3^{\prime}$ end of the miRNA [119]. Current evidence suggests that the miRNAs enclosed in EVs can increase their half-life in circulation, averting the degradation from RNases present in blood [120]. The EV-mediated transfer of miRNAs has been shown to have several physiological roles, for example in the immune response [121]. The selective removal of miRNAs in EVs is also a regulation mechanism, especially the removal of tumor suppressor miRNA in cancer [122,123]. Although it was believed that vesicle encapsulation was the principal mode of stabilization for ex-miRNAs [124], increasing evidence shows 
that the vast majority of small RNAs exported by mammalian cells are principally associated with ribonucleoproteins more than vesicles [125], particularly with Argonaute (AGO) proteins [126,127]. miRNAs have also been found in apoptotic bodies [128] and associated in complexes with high-density lipoprotein (HDL) $[129,130]$. It has been demonstrated that these lipoproteins transport endogenous miRNAs and deliver them to the recipient cells; this important discovery suggests that some of the biological effects of HDL could be mediated by these miRNAs. The functional uptake of miRNAs has only been observed in membrane associated and lipoprotein transporters, but not for miRNA/protein complexes. The functional uptake is usually defined as the capability of the exogenous miRNA, transferred within the exosome, to selectively influence the gene expression in the host cell [129].

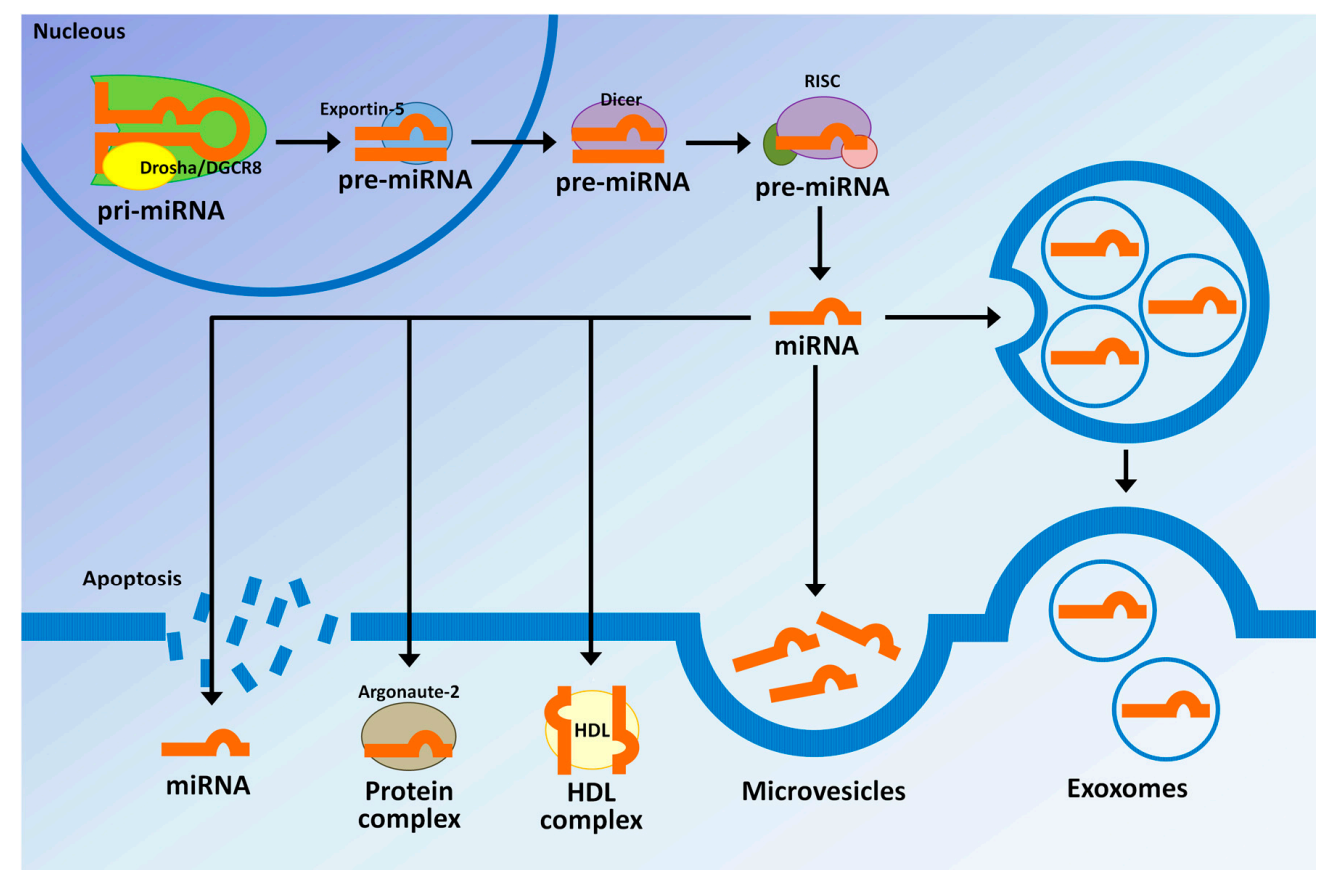

Figure 1. Origin mechanism of circulating microRNAs. MicroRNAs are exported from cells into circulation by free vesicles (active secretion via exosomes and microvesicles) and are associated with ribonucleoproteins, particularly with Argonaute (AGO) proteins. miRNAs have also been found in apoptotic bodies and associated with complexes with high density lipoprotein (HDL).

\section{5. miRNAs as Biomarkers in Biliary Tract Cancer: miRNAs in Blood (Plasma and Serum), Bile and Gallstones}

\subsection{Plasma/Serum miRNA Panels as Biomarkers}

Meng et al. described the first approach by which miRNAs could be used as biomarkers in cholangiocarcinoma. They found that miR-21 and miR-200b are related to sensitivity/resistance to gemcitabine [131]. Various current publications have reported on the potential clinical application of circulating miRNAs in BTCs for diagnosis and prognosis; most have focused on CCA, with little information being provided on GBC and ampullary adenocarcinoma. Li et al. [132] analyzed the expression of circulating miRNAs in patients with GBC, finding that miR-21, miR-187 and miR-202 were upregulated; by contrast, let-7a, miR-143 and miR-335 were downregulated between GBC patients and healthy controls $(p<0.05)$, showing a consistent expression in tissue and blood samples. Moreover, a significant relationship was found between the differential expression of three miRNAs (miR-187, miR-143 and miR-202) and lymphatic metastasis/TNM [132]. These data are consistent with the prior report performed by Kishimoto et al. [30], where expression levels of miR-21 in patients with BTCs (including intrahepatic cholangiocarcinoma, bile duct cancer, gallbladder cancer and cancer of the 
ampulla of Vater) were significantly higher than in healthy controls or in patients with BBDs, with the area under the curve (AUC) for plasma being 0.93 and 0.83 , respectively (Table 1 ). The sensitivity and specificity was $85.1 \%$ and $100 \%$, respectively, for healthy controls and $72.3 \%$ and $91.3 \%$ for BBDs [30]. In addition, the high expression of miR-21 was associated with the progression of TNM staging, and the diagnostic power increased by the combined use of CA19-9 and miR-21 for distinguishing between BTCs and healthy controls. Interestingly, circulating miR-21 expression decreased after surgery [30]. Furthermore, miR-21 is uniformly overexpressed in human CCA tissue and cell lines, possessing a sensitivity and specificity of $95 \%$ and $100 \%$ (AUC of 0.995 ), respectively, enough to differentiate CCA from normal tissues [22,133].

Table 1. Area under the curve (AUC), sensitivity and specificity values of miRNAs in plasma and bile samples, according to different histological conditions of biliary tract cancers.

\begin{tabular}{|c|c|c|c|c|}
\hline miRNAs & AUC & Sensitivity & Specificity & Reference \\
\hline $\begin{array}{l}\text { BTCs vs. HVs } \\
\text { miR-21 }\end{array}$ & 0.93 & $85.1 \%$ & $100 \%$ & \multirow{2}{*}{ Kishimoto et al. [30] } \\
\hline $\begin{array}{l}\text { BTCs vs. BBD } \\
\text { miR-21 }\end{array}$ & 0.83 & $72.3 \%$ & $91.3 \%$ & \\
\hline $\begin{array}{l}\text { iCCA vs. controls } \\
\text { miR-150 }\end{array}$ & 0.764 & $80.6 \%$ & $58.1 \%$ & Wang et al. [134] \\
\hline $\begin{array}{l}\text { iCCA vs. HVs } \\
\text { miR-192 }\end{array}$ & 0.803 & $74 \%$ & $72 \%$ & Silakit et al. [135] \\
\hline $\begin{array}{l}\text { PSC vs. CCA (serum) } \\
\text { miR-1281 } \\
\text { miR-126 } \\
\text { miR-26a } \\
\text { miR-30b } \\
\text { miR-122 }\end{array}$ & $\begin{array}{l}0.83 \\
0.87 \\
0.78 \\
0.78 \\
0.65\end{array}$ & $\begin{array}{l}55 \% \\
68 \% \\
52 \% \\
52 \% \\
32 \%\end{array}$ & $\begin{array}{l}90 \% \\
93 \% \\
93 \% \\
88 \% \\
90 \%\end{array}$ & \multirow{2}{*}{ Voigtlander et al. [136] } \\
\hline $\begin{array}{l}\text { PSC vs. CCA (bile) } \\
\text { miR-412 } \\
\text { miR-640 } \\
\text { miR-1537 } \\
\text { miR-3189 }\end{array}$ & $\begin{array}{l}0.81 \\
0.81 \\
0.78 \\
0.80\end{array}$ & $\begin{array}{l}50 \% \\
50 \% \\
67 \% \\
67 \%\end{array}$ & $\begin{array}{l}89 \% \\
92 \% \\
90 \% \\
89 \%\end{array}$ & \\
\hline $\begin{array}{l}\text { PSC vs. HVs } \\
\text { miR-200c }\end{array}$ & 0.74 & - & - & \multirow{3}{*}{ Bernuzzi et al. [137] } \\
\hline $\begin{array}{l}\text { CCA vs. HVs } \\
\text { miR-483-5p } \\
\text { miR-194 } \\
\text { miR-483-5p and miR-194 }\end{array}$ & $\begin{array}{l}0.77 \\
0.74 \\
0.81\end{array}$ & $\begin{array}{l}- \\
- \\
-\end{array}$ & $\begin{array}{l}- \\
- \\
-\end{array}$ & \\
\hline $\begin{array}{l}\text { CCA vs. PSC } \\
\text { miR-222 } \\
\text { miR-483-5p } \\
\text { miR-222 and miR-483-5p }\end{array}$ & $\begin{array}{l}0.71 \\
0.70 \\
0.77\end{array}$ & $\begin{array}{l}- \\
- \\
-\end{array}$ & $\begin{array}{l}- \\
- \\
-\end{array}$ & \\
\hline $\begin{array}{l}\text { PBC vs. HVs } \\
\text { Combination of eight } \\
\text { miRNAs (miR-6075, miR-4294, } \\
\text { miR-6880-5p, miR-6799-5p, } \\
\text { miR-125a-3p, miR-4530, } \\
\text { miR-6836-3p, and miR-4476) }\end{array}$ & 0.953 & $80.3 \%$ & $97.6 \%$ & Kojima et al. [138] \\
\hline $\begin{array}{l}\text { BTCs vs. choledocholithiasis } \\
\text { miR-9 } \\
\text { miR-145* } \\
\text { miR-944 }\end{array}$ & $\begin{array}{l}0.975 \\
0.975 \\
0.765\end{array}$ & $\begin{array}{l}88.9 \% \\
77.8 \% \\
77.8 \%\end{array}$ & $\begin{array}{l}100 \% \\
100 \% \\
100 \%\end{array}$ & Shigehara et al. [114] \\
\hline $\begin{array}{l}\text { CCA vs. HVs } \\
\text { miR-106a }\end{array}$ & 0.89 & $81.6 \%$ & $85 \%$ & Cheng et al. [139] \\
\hline
\end{tabular}


Plieskatt et al. [40] performed a comprehensive analysis of profiled miRNA expression levels in iCCA tumor tissue and matched plasma samples. The analysis of miRNAs in plasma was based on the aberrant expression observed in tissues. It was found that the expression of eight miRNAs (miR-483-5p, miR-505-3p, miR-874, miR-885-5p, miR-320b, miR-92b-3p, miR-1275 and miR-1307-3p) was detected exclusively in all iCCA plasma samples and not in controls plasma [40]. In addition, the aberrant microRNA expression in tissues was not similar to that observed in plasma, where fifteen of the highly deregulated miRNAs were only detected in tissues samples. This expression profile in plasma could be useful as a biomarker for the early detection of iCCA. Similarly, Wang et al. [134] studied the expression of miRNAs in tissue and matched plasma samples, reporting that miR-150 presented the most significant expression level and was upregulated in ICC plasma patients, with the opposite result being observed in tissue, where it was downregulated. No significant differences were found between the levels of miR-150 and age, gender or clinical stage of patients. Based on the ROC analysis, plasma miR-150 could be used to distinguish patients with iCCA from healthy volunteers (HVs), with the AUC being $0.764(p<0.010)$, sensitivity $80.6 \%$ and specificity $58.1 \%$. In addition, the diagnostic value is increased when combined with the carbohydrate antigen 19-9 marker, improving patient screening [134]. miR-150, it has been reported, may function as oncogenes or tumor suppressors, is significantly upregulated (acts as an oncogene) in several types of cancers, e.g., in breast cancer [140] and gastric cancer [141], and is significantly downregulated (acts as a tumor suppressor) in colorectal cancer [142] and osteosarcoma [143]. There are no other studies correlating this microRNA with BTCs. Meanwhile, Silakit et al. [135] demonstrated that miR-192 levels were significantly higher in the pooled serum of CCA patients than in pooled HVs, with a sensitivity and specificity of $74 \%$ and $72 \%$, respectively (AUC of 0.803 ). Moreover, miR-192 expression was significantly linked to lymph node metastasis and associated with a poor prognosis in CCA patients [135]. In addition, miR-200b expression was also significantly higher in CCA patients than HVs [135], but this miR-200b expression was relatively lower compared to miR-192. In tissues, a high expression of miR-192 was observed in $53 \%$ of tumor cases compared toadjacent non-tumor tissues; however, no significant difference was found [135]. Huang et al. [144] found that miR-224 was significantly upregulated in serum, as well as in cancer tissue from CCA patients compared to healthy controls. Furthermore, the human CCA cell lines transfected with a miR-224 mimic showed enhanced cell growth, invasiveness and migratory ability [144]. Kojima et al. [138] studied a large number of cases of gastrointestinal cancers, including BTCs (intrahepatic and extrahepatic bile duct, gallbladder, hilar bile duct and ampulla of Vater) and healthy controls. They found that 66 miRNAs showed statistical significance in the validation cohort (test cohort), among which 30 miRNAs were upregulated and 36 miRNAs were downregulated in BTCs. Expression of miR-125a-3p and miR-6893-5p showed the lowest $p$-values in a comparison of BTCs and HVs. In addition, miR-125a-3p was able to detect 32 of 33 patients $(97.0 \%)$ in the test cohort [138]. Unfortunately, miR-125a-3p lacks some specificity because it was described as a reliable marker for pancreatic cancer, and a strong overlap is observed in the expression of this miRNA between these two types of cancers. At the same time, Que et al. [145] evaluated the expression partially of circulating miRNAs in AC. Four miRNAs (miR-17-5p, miR-21, miR-155 and miR-196a) related to pancreatic adenocarcinoma (PA) were selected to evaluate serum exosomal miRNA levels. No significant differences were found in the expression levels of miR-21 and miR-17-5p between PC patients and AC patients, although they tended to be lower in AC patients. Furthermore, expression of these miRNAs in AC tended to be higher than in healthy controls [145]. According to these results, none of the selected miRNAs reached statistical significance to discriminate between pancreatic cancer and BTCs.

Another study performed by Cheng et al. [139] found that circulating miR-106a is downregulated in CCA patients compared to BBD patients or healthy controls. Moreover, the serum level of miR-21 was higher in CCA patients than in BBD controls; however, no statistically-significant differences were found. The AUC of serum miR-106a for differentiating CCA patients from healthy controls was 0.89 ; the sensitivity and specificity for this marker were $81.6 \%$ and $85.0 \%$, respectively. This result is 
moderate and higher than serum CA19-9. Meanwhile, downregulation of miR-106a in serum samples was associated with lymph node metastasis and poor prognosis in CCA patients [139].

\subsection{Bile miRNA Panels as Biomarkers}

Bile is a fluid produced by the liver and secreted into the intestine through biliary ducts to help digest fats. It is mainly composed of water, salts from biliary acids, compounds of glycolic and taurocholic acid and bile pigments (bilirubin), as well as proteins, electrolytes, mucus and various metabolites [146], such as miRNAs, which have been proposed as excellent biomarkers in the diagnosis of gastrointestinal tumors [147,148]. It has also been reported that extracellular vesicles are present in human bile and contain a large number of miRNAs [24], which makes these molecules very stable [114]. Li et al. [24] defined a novel biliary microvesicle-"laden" miR-based panel for CCA diagnosis, combining five miR markers (miR-191, miR-486-3p, miR-1274b, miR-16 and miR-484) that were able to differentiate between CCA from primary sclerosing cholangitis or other bile duct obstruction, with a sensitivity of $67 \%$ and a specificity of $96 \%$. Considering the individual expression of miRNAs, miR-486-3p has a greater diagnostic value for CCA [24]. Similarly, Shigehara et al. [114] demonstrated that 10 of the 667 bile miRNAs studied (miR-9, miR-145*, miR-105, miR-147b, let-7f-2*, let-7i*, miR-302c*, miR-199a-3p, miR-222* and miR-942) were significantly more highly expressed in the malignant group composed of CCA and GBC patients than in the control group (patients with choledocholithiasis). Moreover, ROC analysis showed that the combination of two miRNAs (miR-9 and $\mathrm{miR}-145^{*}$ ) is a suitable diagnostic biomarker for BTCs [114].

A study conducted by Voigtlander et al. [149] revealed that patients with primary sclerosing cholangitis (PSC), a pathology that causes inflammation and obliterative fibrosis of the bile ducts of the liver, increased the risk of developing CCA, having distinct miRNA profiles in serum and bile. A serum validation analysis found significantly higher levels of miR-1281, miR-126, miR-26a, miR-30b and miR-122 in patients with PSC compared to patients with CCA. All of the validated circulating miRNAs were significantly higher in the abnormal cases than in HVs. By contrast, miR-412, miR-640, miR-1537 and miR-3189 expression was different between patients with PSC and PSC/CCA in bile samples [136], of which only miR-412 was upregulated [149]. Similarly, Bernuzzi et al. [137] also attempted to identify a miRNA panel for the diagnosis of PSC-related to CCA, but only in serum samples. It was found that miR-200c is significantly downregulated in PSC versus HVs, whereas miR-483-5p and miR-194 were upregulated in CCA compared to HVs. If we observe what occurs between CCA with PSC, as in the previous study, miR-222 and miR-483-5p were found to be upregulated in CCA versus PSC [137]. Patients with PSC and/or CCA have distinct miRNA profiles in serum and bile; thus, these miRNA expressions could possibly be used to detect an early lesion. However, in this study, Voigtlander et al. [149] could not use matched samples (blood and bile) from the same patients to establish this differentiation.

\section{3. miRNA Biomarkers in Gallstones for the Identification of High-Risk Patients with Complications in the Biliary Tract}

Gallstones are an important risk factor associated with GBC, being present in most ( 85\%) patients [150]. The expression profile of miRNAs in gallstones could represent a new way to assess the degree of injury that the epithelium could potentially present in these patients. The formation of gallstones occurs as a consequence of the excess of cholesterol precipitation in bile caused by a variety of factors that involve cholesterol absorption, biosynthesis and conversion [151]. Interestingly, Yang et al. [152] evaluated the miRNA expression in gallstone tissue, finding that miR-210, miR-200c, miR-194 and miR-192 expression was significantly upregulated and miR-133a and miR-891a expression significantly downregulated in patients with gallstones compared to those without gallstones [152]. The miRNA-200 cluster (miR-200a, miR-200b and miR-200c) has been associated with human GBC via epigenetic regulation [153] and contributes to bile duct proliferation in the cholestatic liver [154]. Additionally, a circulating miR-200b/429 cluster was shown to be significantly increased in the sera 
of biliary atresia suggesting its use as potential biomarkers [155], and the expression of miR-133 was consistently found decreased in tumors and GBC cell lines compared to normal gallbladder tissues [21]. However, in the study by Yang et al. [152], all patients included were confirmed as having no inflammation in the tissue.

Related studies on the synthesis of cholesterol and human gallstones have shown that the FXR/SHP pathway regulates the miR-34a expression and its target SIRT1, which is associated with gallstones because it participates in lipid metabolism and hepatic bile acid synthesis [156]. The farnesoid X receptor (FXR) is an important regulator of bile formation, controlling the secretion of phospholipids, bile salts, and is also associated with the regulation of liver $\mathrm{X}$ receptors (LXR), secretion modulators [157]. Recently, it was observed that the activation of FXR regulates SREBP-2 and miR-33 expressionand the regulation of their specific target genes [158]. miR-33 inhibits expression of the mRNAs ABCB11 and ATP8B1, which results in changes in bile secretion and bile recovery from the gallbladder [159]. In addition, ATP-binding cassette transporter A1 (ABCA1) is a major determinant of HDL-cholesterol levels, and its expression is regulated by miR-144 [160]; and miRNAs 122a and 422a may inhibit the human cholesterol 7a-hydroxylase mRNA (CYP7A1), which is intricately involved in regulating bile acid synthesis in the liver [161]. Several miRNAs have a major influence on cholesterol homeostasis, including miR-122 [162], miR-370 [163], miR-378/378* [164], miR-143, miR-27 [165], miR-335 [166], and miR-33a/b [167,168], miR-27a [169], miR-223 [170], miR-181a [171], miR-185 [172] and miR-223 [173]. The physicochemical imbalance between the major bile lipids produces hypersecretion of cholesterol in the bile, necessary to saturate the gallbladder and therefore determining individual predisposition to develop gallstones [174,175]. Thus, miRNAs in gallstones and/or deregulation of miRNAs involved in cholesterol homeostasis may be critical in the formation of gallstones, providing a new option for primary detection in subjects at risk ofdeveloping a malignancy or GBC development.

\section{Discussion}

The diagnosis of BTCs is mainly based on imaging, laparoscopic cholecystectomies and intraoperative exploration performed for cholelithiasis [150]. The examination of cells from the mucosa of the biliary tract can be performed through a brush cytology, which has a high specificity, but a low sensitivity, mainly due to the anatomical location of the gallbladder lesions for specimen collection [176]. Brush cytology is an invasive technique that may be useful as a screening procedure; however, this technique does not replace tissue biopsy. Therefore, more sensitive and non-invasive methods are needed in order to distinguish between patients with or without gallbladder lesions. Emerging evidence has shown that miRNA expression might be altered during various pathological conditions and may become non-invasive and specific molecular diagnostic or prognostic markers for human pathology [177]. This is mainly because they have great stability in various types of body fluids, including blood, urine, tears, colostrum, breast milk, bronchial lavage, amniotic, pleural, seminal, peritoneal and cerebrospinal fluids [178]. Furthermore, they are resistant to endogenous RNase digestion, and the laboratory detection methods are sensitive $[179,180]$. The first study to determine the presence of circulating miRNAs was conducted by Lawrie et al. [181] in 2008 on patients with diffuse large B-cell lymphoma, finding that high miR-21 expression was associated with relapse-free survival [181]. The role and expression of miRNAs in BTCs have been gradually explored; various miRNAs have been detected initially in tissues. In GBC, multiple miRNAs have been reported as downregulated compared to normal tissues, such as miR-1, miR-145 [21], miR-135a-5p, miR-26a [182,183], miR-34a [184], miR-335 [185], miR-130a [186] and miR-218-5p [187], and others miRNAs have been upregulated, such as miR-155 [188], miR-20a [189] and miR-182 [190]. In addition, some of these miRNAs (miR-26 [191], miR-34a [131] and miR-155 [192]) also exhibited differential expression in CCA. Meanwhile, miR-21, miR-141 and miR-200b are highly overexpressed in CCA cells, and inhibition of miR-21 and miR-200b is associated with sensitivity to gemcitabine [22,131]. Furthermore, miR-21 showed $95 \%$ sensitivity and $100 \%$ specificity in distinguishing between CCA and 
normal tissues [22]. Selaru et al. [22] determined in 2009 an expression profile of miRNAs in primary extrahepatic CCA; several miRNAs (miR-106b, miR-21, miR-107, miR-106a, miR-93, miR-27a, miR-19a, miR-103, miR 17-5p, miR-25) were found overexpressed, whereas expression of miR-560, miR-370, miR-198, miR-188, miR-662, miR-191, miR-512-3p, miR-520e, miR-513 and miR-494 was repressed [22]. Similarly, Chen et al. [133] identified a more significant expression profile in intrahepatic CCA, correlating mir-200C, miR-141, miR-223 and miR-204 with multifocal cholangiocarcinoma and vascular invasion. There is less scientific evidence in AC tissues, but a microRNA profile has been identified that would allow ampullary adenocarcinomas to be subclassified into pancreatobiliary or intestinal type [23]. Furthermore, miR-215 is the most significantly overexpressed in AC, whereas miR-134 and miR-214 were significantly lower in AC than in pancreatic carcinomas [193]. These unique expression profiles in tissue miRNAs could probably correlate with circulating levels and may be excellent candidates for biomarkers in the serum, plasma and bile of these patients. However, as observed in different studies, the expression of miRNAs in tissue in matched plasma was not always the same; for example, Plieskatt $e t$ al. [40], found that the expression of the eight miRNAs was detected exclusively in all iCCA plasma samples and not in control plasma and tissue samples. Conversely, 15 highly deregulated miRNAs in tumor tissue were absent in paired plasma samples, deregulated exclusively in tumor tissue. Similarly, Wang et al. [134] demonstrated that miR-150 was upregulated in iCCA plasma patients, observing an opposite result to matched tissue. As reported by other publications (not matched samples), for example, Shigehara et al. [114] demonstrated that in bile miR-145* was significantly upregulated in CCA and GBC compared to patients diagnosed with choledocholithiasis; however, our work published in 2014 found that in tissue, miR-145 was downregulated in GBC, compared to non-neoplastic tissues [21]. This may reflect different functions present in tissue and in circulating miRNAs. One of the mechanisms through which circulating miRNAs originate is active secretion via exosomes [107], where they are encapsulated in the extracellular vesicles in circulation blood and bile. It has been found that liver and biliary tree cells communicate through EVs and extracellular vesicle-transported miRNA species [194]. This suggests an active mechanism to selectively export or import miRNAs. It is an interesting route that could explain this phenomenon, since the miRNA profiles of exosomes may differ in tissue and plasma [195]; therefore, the expression level could vary from tissue and blood samples. This is consistent with that reported by Pigati et al. [196], who hypothesized the existence of an intrinsic mechanism of selection within cells for miRNA secretion, explaining the different cellular and extracellular miRNA profiles. Thereby, the secreted miRNAs do not necessarily reflect the amount of miRNAs in the origin cell [196].

In contrast, miR-192 levels were significantly higher in the serum and tissues of CCA patients; however, no significant difference was found in tissues [135]; miR-224 was significantly upregulated in serum, as well as in tissue from CCA patients [144]; and circulating mir-21 is upregulated in GBC [132] and CCA [30], as well as in the tissue of CCA patients [197]. Interestingly, it has been reported that miR-21 is highly overexpressed in GBC cell lines (NOZ) treated with aquaporin-5 (AQP-5) siRNA, and genetic defects involving aquaporin genes have been associated with GBC [198].

miR-21 has been characterized as playing an important role in BTCs [30,132], and it has been suggested that it could have a potential role as in early diagnostic biomarker. Previous reports have also shown that circulating miR-21 expression increases in inflammatory conditions [199]. However, in studies by Kishimoto et al. [30] and Cheng et al. [139], plasma miR-21 was capable of distinguishing BTC patients from BBD. Distinguishing BTCs and BBD is very difficult to achieve by detecting the standard tumor markers, such as CA19-9 [200]. The determination of the primary disease site in advanced stages is key for applying the appropriate treatment and obtaining the desire results in survival; however, this determination is currently too challenging to achieve without invasive diagnostic methods. On the other hand, miR-21 may lack specificity, because it is one of the most commonly deregulated circulation miRNAs in diseases such as liver cancer [201], esophageal cancer [202], prostate cancer [203], head and neck cancer [204], gastric cancer [205], lung cancer [206], lymphoma [181] and colorectal cancer [207]. Therefore, the use of single and/or multiple miRNA 
expressed as a profile/pattern and combined with other classic biomarkers measured in plasma/serum could provide more specific and relevant information to diagnose and predict BTCs. Thus, a single biomarker might not reflect the complexity of a disease, and a multimarker strategy may improve the sensitivity and specificity at diagnosis and prognosis. For example, Li et al. [24] defined a panel combining five miRNA markers for CCA diagnosis, and Shigehara et al. [114] demonstrated that the combination of two miRNAs (miR-9 and miR-145*) is a suitable diagnostic biomarker for BTCs. Meanwhile, Kishimoto et al. [30] showed that diagnostic power increases by using a combination of CA19-9 and miR-21 to differentiate BTC patients from healthy volunteers and BBD patients. Similarly, Wang et al. [134] showed that the diagnostic value is increased when miR-150 expression and CA19-9 are combined, improving patient screening. In contrast, Voigtlander et al. [136] showed that the diagnostic value is not increased by using a panel of miRNAs to differentiate patients with PSC from CCA.

In this manuscript, distinct expression patterns of circulating miRNAs have been observed, including some inconsistencies in the results. It is likely that the inconsistency in some data reported in the literature is due to ethnic variations [208]. Li et al. [24] delineated a different miRNA pattern to detect CCA in bile, including a multiethnic population (Caucasian, African American, Asian and Hispanic) in the analysis. Considering this variable and although most cases are Caucasian, this analysis is probably more representative of the general population. Considering that miRNAs may be circulating in different forms (freely circulating, bound to proteinsor enclosed in EVs) [108], multiple purification strategies should be considered to enable work with groups of circulating miRNAs separately, thus avoiding a biased group of miRNAs potentially having completely different physiological functions. Li et al. [24] and Que et al. [145] studied miRNA species solely isolated from EVs with no consideration of the soluble fraction of bile. In addition, RNAs extracted from free-floating cells in bile [24] and isolated from clinical samples of bile and biliary brushings have been shown to be highly degraded [209]. Meanwhile, due to the technical feasibility of obtaining biological material, many researchers cannot evaluate the expression of miRNAs in paired samples and obtain tissue from healthy patients (with no pre-neoplastic lesion), and as the bile collection is an invasive technique, healthy patients do not undergo biliary brushings by ERCP for use as a healthy control and to establish a baseline, which makes the analysis of this complex epigenetic mechanism limited and difficult. In the same context, most studies used samples from "healthy volunteers" as controls, and other studies used samples from benign bile-duct disease (BBD) as controls. Therefore, unfortunately, the expression profile of microRNAs in different preneoplastic stages (hyperplasia, metaplasia and dysplasia) is not comparable. Moreover, BBD controls are formed by large heterogeneous groups with an interesting biological diversity. For instance, Kishimoto et al. [30] included patients with gallstones, cholecystitis, adenomyomatosis, gallbladder polyp, cholangitis, choledocal cyst, malfusion of pancreaticobiliary duct, bile duct dysplasia and postoperative stenosis in their study. Similarly Li et al. [24] included patients with benign biliary obstruction, primary sclerosing cholangitis, sphincter of Oddi dysfunction, chronic pancreatitis and cholangitis as bile control. Meanwhile, in other reports [139], the histological grade of lesions was not informed. Other factors, such as the standardization of the collecting, transporting and storing the bile sample, as well as the molecular technique and its methodological variables (housekeeping gene), are factors that influence miRNA expression. When considering the minimum amount of sample (whole blood, bile, plasma or serum) required to perform the exRNA extraction, Yang et al. [210] established a reliable method to detect circulating miRNAs in $100 \mu \mathrm{L}$ of blood sample in bile duct-ligated (BDL) mice; this is important in systemically-compromised patients, where sample collection can be complex prior to analysis in the laboratory. Other reports are: Kishimoto et al. [30] extracted total RNA from $400 \mu \mathrm{L}$ of plasma; Plieskatt et al. [40] used $200 \mu \mathrm{L}$ of plasma; Voigtländer et al. [136] used approximately $0.5-5 \mathrm{~mL}$ of bile sample; and Li et al. $400 \mu \mathrm{L}$ of bile [24]. 


\section{Concluding Remarks}

In the context of cancer biology, as with other malignancies, BTCs exhibit an aberrant expression of miRNAs with a marked difference according to the stage and carcinogenic model. Table 2 summarizes all of those circulating miRNAs with the potential to become diagnosis biomarkers due to their significant deregulation in BTCs compared to healthy controls or benign lesions. Some of these miRNAs have the potential to become biomarkers for BTC diagnosis, such as miR-21, miR-187, miR-202 miR-483-5p, miR-505-3p, miR-150, miR-1281, miR-126, miR-26a, miR-200c, miR-9, miR-145*, miR-105, miR-106 and miR-224, as well as to predict prognosis, for instance, miR-187, miR-202, miR-143, mir-21, mir-192 and miR-106a. Specifically, miR-191, miR-486-3p, miR-1274b, miR-16 and miR-484 detected in bile specimens were clinically useful for noninvasive CCA diagnoses of PSC and benign biliary obstruction (BBO) [24], and miR-192 and miR-106a were found to be related to CCA aggressiveness and survival [135,139]. Moreover, miR-21 expression correlates with tumor progression [30], and a significant relationship was found between miR-187, miR-143 and miR-202 and lymphatic metastasis/TNM [132]. Collectively, these data reflect that circulating miRNAs could be used as potential biomarkers for clinical use, for the early detection and prognosis of BTCs [211]. In this context, the content of miRNAs [108] has characteristics according to the ideal biomarker, such as: accessibility, high sensitivity and specificity, early detection of disease and comparatively long half-life [212]. However, to date, few studies have specifically addressed the significance of circulating miRNAs in BTC patients, and further research is required.

Table 2. Circulating miRNAs with potential to become markers in biliary tract cancers.

\begin{tabular}{|c|c|c|c|c|c|c|}
\hline $\begin{array}{l}\text { miRNAs: Up-/ } \\
\text { Down-Regulation }\end{array}$ & Samples Number & $\begin{array}{l}\text { Type of } \\
\text { Sample }\end{array}$ & $\begin{array}{l}\text { Diagnosis/ } \\
\text { Prognosis } \\
\text { Potential }\end{array}$ & $\begin{array}{l}\text { Origin of } \\
\text { Specimen }\end{array}$ & Relevance & Reference \\
\hline $\begin{array}{l}\text { Up: miR-21, miR-187, } \\
\text { and miR-202 } \\
\text { Down: let-7a, } \\
\text { miR-143 and miR-335 }\end{array}$ & GBC (40); HVs (40) & Plasma & $\begin{array}{l}\text { All } \\
\text { diagnosis/only } \\
\text { miR-187, } \\
\text { miR-202 and } \\
\text { miR-143 } \\
\text { prognosis }\end{array}$ & China & GBC versus HVs & Li et al. [132] \\
\hline Up: miR-21 & $\begin{array}{l}\text { BTCs (94) including } \\
\text { CCA, GBC and AC; } \\
\text { HVs (50); BBD (23) }\end{array}$ & Plasma & $\begin{array}{l}\text { Diagnosis and } \\
\text { prognosis }\end{array}$ & Japan & $\begin{array}{l}\text { BTCs versus HVs } \\
\text { and BTCs versus } \\
\text { BBD }\end{array}$ & $\begin{array}{l}\text { Kishimoto et al. } \\
\text { [30] }\end{array}$ \\
\hline $\begin{array}{l}\text { Up: miR-483-5p, } \\
\text { miR505-3p, miR874, } \\
\text { miR885-5p, miR-320b, } \\
\text { miR-92b-3p, miR1275 } \\
\text { and miR1307-3p }\end{array}$ & iCCA (13); HVs (5) & Plasma & Diagnosis & Thailand & iCCA versus HVs & $\begin{array}{l}\text { Plieskatt et al. } \\
\text { [40] }\end{array}$ \\
\hline Up: miR-150 & iCCA (15) & Plasma & Diagnosis & China & $\begin{array}{l}\text { iCCA versus } \\
\text { controls }\end{array}$ & Wang et al. [134] \\
\hline Up: miR-192 & iCCA (51); HVs (32) & Serum & $\begin{array}{l}\text { Diagnosis and } \\
\text { prognosis }\end{array}$ & Thailand & iCCA versus HVs & Silakit et al. [135] \\
\hline $\begin{array}{l}\text { Up (serum samples): } \\
\text { miR-1281, miR-126, } \\
\text { miR-26a, miR-30b and } \\
\text { miR-122 } \\
\text { Down (bile samples): } \\
\text { miR-412, miR-640, } \\
\text { miR-1537 } \\
\text { Up (bile samples): } \\
\text { miR-3189 }\end{array}$ & $\begin{array}{l}\text { PSC ( } 40 \\
\text { serum,52bile); CCA } \\
\text { ( } 31 \text { serum, } 19 \text { bile); } \\
\text { PSC/CCA ( } 12 \text { bile); } \\
\text { HVs (12 serum) }\end{array}$ & Serum/bile & Diagnosis & Germany & PSC versus CCA & $\begin{array}{l}\text { Voigtlander et al } \\
\text { [136] }\end{array}$ \\
\hline $\begin{array}{l}\text { Down: miR-200c } \\
\text { (PSC vs. HVs) } \\
\text { Up: miR-483-5p and } \\
\text { miR-194 } \\
\text { (CCA vs. HVs) } \\
\text { Up: miR-222 and } \\
\text { miR-483-5p } \\
\text { (CCA vs. PSC) }\end{array}$ & $\begin{array}{l}\text { CCA (70); PSC (70); } \\
\text { HVs (70) }\end{array}$ & Serum & Diagnosis & Italy & $\begin{array}{l}\text { PSC versus HVs; } \\
\text { CCA versus HVs; } \\
\text { CCA versus PSC }\end{array}$ & $\begin{array}{l}\text { Bernuzzi et al. } \\
\text { [137] }\end{array}$ \\
\hline
\end{tabular}


Table 2. Cont

\begin{tabular}{|c|c|c|c|c|c|c|}
\hline $\begin{array}{l}\text { miRNAs: Up-/ } \\
\text { Down-Regulation }\end{array}$ & Samples Number & $\begin{array}{l}\text { Type of } \\
\text { Sample }\end{array}$ & $\begin{array}{l}\text { Diagnosis/ } \\
\text { Prognosis } \\
\text { Potential }\end{array}$ & $\begin{array}{l}\text { Origin of } \\
\text { Specimen }\end{array}$ & Relevance & Reference \\
\hline $\begin{array}{l}\text { Down: miR-125a-3p } \\
\text { and miR-6893-5p }\end{array}$ & $\begin{array}{l}\text { BTCs (98) including } \\
\text { iCCA, eCCA, GBC, } \\
\text { HBD and AC; } \\
\text { HVs (150) }\end{array}$ & Serum & Diagnosis & Japan & BTCs versus HVs & $\begin{array}{l}\text { Kojima et al. } \\
\text { [138] }\end{array}$ \\
\hline $\begin{array}{l}\text { Up: miR-191, } \\
\text { miR-486-3p, } \\
\text { miR-1274b, miR-16 } \\
\text { and miR-484 }\end{array}$ & $\begin{array}{l}\text { CCA (46); Control } \\
\text { group (50) including } \\
\text { BBO, PSC, SOD, CP } \\
\text { and cholangitis }\end{array}$ & Bile in EVs & Diagnosis & $\begin{array}{l}\text { USA (Including } \\
\text { Caucasian;African } \\
\text { American; Asian } \\
\text { and Hispanic) }\end{array}$ & $\begin{array}{l}\text { CCA versus PSC } \\
\text { and } \mathrm{BBO}\end{array}$ & Li et al. [24] \\
\hline $\begin{array}{l}\text { Up: miR-9, miR-145 *, } \\
\text { miR-105, miR-147b, } \\
\text { let-7f-2*, let-7i*, } \\
\text { miR-302c }{ }^{*}, \\
\text { miR-199a-3p, } \\
\text { miR-222* and miR-942 }\end{array}$ & $\begin{array}{l}\text { BTCs (9) including } \\
\text { CCA and GBC; } \\
\text { Choledocholithiasis (9) }\end{array}$ & Bile & Diagnosis & Japan & $\begin{array}{l}\text { BTCs versus } \\
\text { choledocholithiasis }\end{array}$ & $\begin{array}{l}\text { Shigehara et al. } \\
\text { [114] }\end{array}$ \\
\hline $\begin{array}{l}\text { Down: miR-21 and } \\
\text { miR-17-5p (no } \\
\text { significant difference) }\end{array}$ & $\begin{array}{l}\mathrm{PC}(22) ; \mathrm{AC}(6) ; \mathrm{HVs} \\
(8)\end{array}$ & $\begin{array}{l}\text { Serum in } \\
\text { EVs }\end{array}$ & - & China & AC versus PC & Que et al. [145] \\
\hline $\begin{array}{l}\text { Up: miR-210, } \\
\text { miR-200c, miR-194 } \\
\text { and miR-192 } \\
\text { Down: miR-133a and } \\
\text { miR-891a }\end{array}$ & $\begin{array}{l}\text { Choledochol ithiasis } \\
\text { and HVs }\end{array}$ & Gallstones & - & China & $\begin{array}{l}\text { Choledocholithiasis } \\
\text { versus HVs }\end{array}$ & Yang et al. [152] \\
\hline Up: miR-224 & CCA (30); HVs (50) & Serum & Diagnosis & China & CCA versus HVs & $\begin{array}{l}\text { Huang et al. } \\
{[144]}\end{array}$ \\
\hline
\end{tabular}

CCA: Cholangiocarcinoma; GBC: gallbladder cancer; AC: ampulla Vater cancer; HVs healthy volunteers; iCCA: intrahepatic cholangiocarcinoma; PSC: primary sclerosing cholangitis; eCCA: extrahepaticcholangiocarcinoma; HBD: hilar bile duct cancer; BBO: benign biliary obstruction; SOD: sphincter of Oddi dysfunction; CP: chronic pancreatitis; BBD: benign bile-duct disease; PA: pancreatic adenocarcinoma; EVs: extracellular vesicles; -: No data.

Acknowledgments: This work was supported by Fondo Nacional de Desarrollo Científico y Tecnológico (FONDECYT) 1130204 and Comisión Nacional de Investigación Científica y Tecnológica (CONICYT)—Fondo de Financiamiento de Centros de Investigación en Áreas Prioritarias (FONDAP) 15130011.

Conflicts of Interest: The authors declare no conflict of interest.

\section{Abbreviations}

3'UTR $\quad 3$ 'Untranslated region

ABCA1 ATP-binding cassette transporter A1

$\mathrm{AC}$

Ampulla Vater cancer

AGO

AQP-5

Argonaute

AUC

Aquaporin-5

BBD

Area under the curve

BBO

Benign biliary diseases

BDL

Benign biliary obstruction

BTCs

CA19-9

Bile duct-ligated

CCA

Biliary tract cancers

CEA

CP

Carbohydrate 19-9

Cholangiocarcinoma

Carcinoembryonic antigen

CT

CYP7A1

Chronic pancreatitis

Computed tomography

dCCA

Cholesterol 7a-hydroxylase mRNA

eCCA

Distal cholangiocarcinoma

ERCP

Extrahepatic cholangiocarcinoma

EUS

Endoscopic retrograde cholangiopancreatography

EVs Extracellular vesicles

Endoscopic ultrasound

EXOmotif miRNAs into exosomes attached to specific motifs 


$\begin{array}{ll}\text { exRNA } & \text { Extracellular RNA } \\ \text { FXR } & \text { Farnesoid X receptor } \\ \text { GBC } & \text { Gallbladder cancer } \\ \text { HBD } & \text { Hilar bile duct cancer } \\ \text { HDL } & \text { High-density lipoprotein } \\ \text { hnRNP } & \text { Ribonucleoprotein } \\ \text { hnRNPA2B1 } & \text { Heterogeneous nuclear ribonucleoprotein A2/B1 } \\ \text { HVs } & \text { Healthy volunteers } \\ \text { iCCA } & \text { Intrahepatic cholangiocarcinoma } \\ \text { LncRNAs } & \text { Long non-coding RNA } \\ \text { LOH } & \text { Loss of heterozygosity } \\ \text { LXR } & \text { Liver X receptors } \\ \text { miRNAs } & \text { microRNAs } \\ \text { miRNA* } & \text { Temporary string miRNA } \\ \text { MRI } & \text { Magnetic resonance imaging } \\ \text { NOZ } & \text { Gallbladder cancer cell lines } \\ \text { PA } & \text { Pancreatic adenocarcinoma } \\ \text { PBC } & \text { Pancreato-biliary cancers } \\ \text { pCCA } & \text { Perihilarcholangiocarcinoma } \\ \text { pre-miRNA } & \text { Precursor miRNA } \\ \text { pri-miRNA } & \text { Primary miRNA } \\ \text { PSC } & \text { Primary sclerosing cholangitis } \\ \text { PTC } & \text { Percutaneous transhepatic cholangiography } \\ \text { RISC } & \text { RNA-induced silencing complex } \\ \text { SOD } & \text { Sphincter of Oddi dysfunction } \\ \text { TNM } & \text { Staging system for classification of malignant tumours } \\ \text { TUTases } & \text { Uridylyltransferases } \\ \text { XPO5 } & \text { Exportin 5 } \\ & \end{array}$

\section{References}

1. Wu, Q.; Kiguchi, K.; Kawamoto, T.; Ajiki, T.; Traag, J.; Carbajal, S.; Ruffino, L.; Thames, H.; Wistuba, I.; Thomas, M.; et al. Therapeutic effect of rapamycin on gallbladder cancer in a transgenic mouse model. Cancer Res. 2007, 67, 3794-3800. [CrossRef] [PubMed]

2. Lin, W.; Jiang, L.; Chen, Y.; She, F.; Han, S.; Zhu, J.; Zhou, L.; Tang, N.; Wang, X.; Li, X. Vascular endothelial growth factor-d promotes growth, lymphangiogenesis and lymphatic metastasis in gallbladder cancer. Cancer Lett. 2012, 314, 127-136. [CrossRef] [PubMed]

3. Beyazit, Y.; Kekilli, M.; Ibis, M.; Kurt, M.; Sayilir, A.; Onal, I.K.; Purnak, T.; Oztas, E.; Tas, A.; Yesil, Y.; et al. Can red cell distribution width help to discriminate benign from malignant biliary obstruction? A retrospective single center analysis. Hepato-gastroenterology 2012, 59, 1469-1473. [PubMed]

4. Zhang, L.; Miao, R.; Zhang, X.; Chen, W.; Zhou, Y.; Wang, R.; Zhang, R.; Pang, Q.; Xu, X.; Liu, C. Exploring the diagnosis markers for gallbladder cancer based on clinical data. Front. Med. 2015, 9, 350-355. [CrossRef] [PubMed]

5. Kau, S.Y.; Shyr, Y.M.; Su, C.H.; Wu, C.W.; Lui, W.Y. Diagnostic and prognostic values of ca 19-9 and cea in periampullary cancers. J. Am. Coll. Surg. 1999, 188, 415-420. [CrossRef]

6. Strom, B.L.; Maislin, G.; West, S.L.; Atkinson, B.; Herlyn, M.; Saul, S.; Rodriguez-Martinez, H.A.; Rios-Dalenz, J.; Iliopoulos, D.; Soloway, R.D. Serum cea and ca 19-9: Potential future diagnostic or screening tests for gallbladder cancer? Int. J. Cancer 1990, 45, 821-824. [CrossRef] [PubMed]

7. Khan, S.A.; Davidson, B.R.; Goldin, R.; Pereira, S.P.; Rosenberg, W.M.; Taylor-Robinson, S.D.; Thillainayagam, A.V.; Thomas, H.C.; Thursz, M.R.; Wasan, H. Guidelines for the diagnosis and treatment of cholangiocarcinoma: Consensus document. Gut 2002, 51 (Suppl. 6), VI1-VI9. [CrossRef] [PubMed]

8. Lu, J.; Getz, G.; Miska, E.A.; Alvarez-Saavedra, E.; Lamb, J.; Peck, D.; Sweet-Cordero, A.; Ebert, B.L.; Mak, R.H.; Ferrando, A.A.; et al. Microrna expression profiles classify human cancers. Nature 2005, 435, 834-838. [CrossRef] [PubMed]

9. Reinhart, B.J.; Slack, F.J.; Basson, M.; Pasquinelli, A.E.; Bettinger, J.C.; Rougvie, A.E.; Horvitz, H.R.; Ruvkun, G. The 21-nucleotide let-7 RNA regulates developmental timing in caenorhabditis elegans. Nature 2000, 403, 901-906. [PubMed] 
10. Cheng, A.M.; Byrom, M.W.; Shelton, J.; Ford, L.P. Antisense inhibition of human miRNAs and indications for an involvement of miRNA in cell growth and apoptosis. Nucleic Acids Res. 2005, 33, 1290-1297. [CrossRef] [PubMed]

11. Chan, J.A.; Krichevsky, A.M.; Kosik, K.S. Microrna-21 is an antiapoptotic factor in human glioblastoma cells. Cancer Res. 2005, 65, 6029-6033. [CrossRef] [PubMed]

12. Sassen, S.; Miska, E.A.; Caldas, C. Microrna: Implications for cancer. Virchows Arch. 2008, 452, 1-10. [CrossRef] [PubMed]

13. Lynam-Lennon, N.; Maher, S.G.; Reynolds, J.V. The roles of microRNA in cancer and apoptosis. Biol Rev. Camb. Philos. Soc. 2009, 84, 55-71. [CrossRef] [PubMed]

14. Nikitina, E.G.; Urazova, L.N.; Stegny, V.N. MicroRNAs and human cancer. Exp. Oncol. 2012, 34, 2-8. [PubMed]

15. Jeffrey, S.S. Cancer biomarker profiling with microRNAs. Nat. Biotechnol 2008, 26, 400-401. [CrossRef] [PubMed]

16. Strimbu, K.; Tavel, J.A. What are biomarkers? Curr. Opin. HIV AIDS 2010, 5, 463-466. [CrossRef] [PubMed]

17. Motawi, T.K.; Rizk, S.M.; Ibrahim, T.M.; Ibrahim, I.A. Circulating microRNAs, miR-92a, miR-100 and miR-143, as non-invasive biomarkers for bladder cancer diagnosis. Cell. Biochem. Funct. 2016. [CrossRef] [PubMed]

18. Bertoli, G.; Cava, C.; Castiglioni, I. Micrornas: New biomarkers for diagnosis, prognosis, therapy prediction and therapeutic tools for breast cancer. Theranostics 2015, 5, 1122-1143. [CrossRef] [PubMed]

19. Braicu, C.; Cojocneanu-Petric, R.; Chira, S.; Truta, A.; Floares, A.; Petrut, B.; Achimas-Cadariu, P.; Berindan-Neagoe, I. Clinical and pathological implications of miRNA in bladder cancer. Int J. Nanomed. 2015, 10, 791-800. [CrossRef] [PubMed]

20. Fujita, Y.; Kuwano, K.; Ochiya, T.; Takeshita, F. The impact of extracellular vesicle-encapsulated circulating microRNAs in lung cancer research. BioMed Res. Int. 2014, 2014, 486413. [CrossRef] [PubMed]

21. Letelier, P.; Garcia, P.; Leal, P.; Alvarez, H.; Ili, C.; Lopez, J.; Castillo, J.; Brebi, P.; Roa, J.C. miR-1 and miR-145 act as tumor suppressor microRNAs in gallbladder cancer. Int. J. Clin Exp. Pathol. 2014, 7, 1849-1867. [PubMed]

22. Selaru, F.M.; Olaru, A.V.; Kan, T.; David, S.; Cheng, Y.; Mori, Y.; Yang, J.; Paun, B.; Jin, Z.; Agarwal, R.; et al. MicroRNA-21 is overexpressed in human cholangiocarcinoma and regulates programmed cell death 4 and tissue inhibitor of metalloproteinase 3. Hepatology 2009, 49, 1595-1601. [CrossRef] [PubMed]

23. Schultz, N.A.; Werner, J.; Willenbrock, H.; Roslind, A.; Giese, N.; Horn, T.; Wojdemann, M.; Johansen, J.S. Microrna expression profiles associated with pancreatic adenocarcinoma and ampullary adenocarcinoma. Mod. Pathol. 2012, 25, 1609-1622. [CrossRef] [PubMed]

24. Li, L.; Masica, D.; Ishida, M.; Tomuleasa, C.; Umegaki, S.; Kalloo, A.N.; Georgiades, C.; Singh, V.K.; Khashab, M.; Amateau, S.; et al. Human bile contains microRNA-laden extracellular vesicles that can be used for cholangiocarcinoma diagnosis. Hepatology 2014, 60, 896-907. [CrossRef] [PubMed]

25. Hsing, A.W.; Rashid, A.; Devesa, S.S.; Fraumeni, J.F. Biliary tract cancer. In Cancer Epidemiology and Prevention, 3rd ed.; Schottenfeld, D., Fraumeni, J.F., Jr., Eds.; Oxford University Press: New York, NY, USA, 2006; pp. 878-900.

26. De Groen, P.C.; Gores, G.J.; LaRusso, N.F.; Gunderson, L.L.; Nagorney, D.M. Biliary tract cancers. N. Engl. J. Med. 1999, 341, 1368-1378. [CrossRef] [PubMed]

27. Shaib, Y.; El-Serag, H.B. The epidemiology of cholangiocarcinoma. Semin. Liver Dis. 2004, 24, 115-125. [CrossRef] [PubMed]

28. Tyson, G.L.; El-Serag, H.B. Risk factors for cholangiocarcinoma. Hepatology 2011, 54, 173-184. [CrossRef] [PubMed]

29. Stinton, L.M.; Shaffer, E.A. Epidemiology of gallbladder disease: Cholelithiasis and cancer. Gut Liver 2012, 6, 172-187. [CrossRef] [PubMed]

30. Kishimoto, T.; Eguchi, H.; Nagano, H.; Kobayashi, S.; Akita, H.; Hama, N.; Wada, H.; Kawamoto, K.; Tomokuni, A.; Tomimaru, Y.; et al. Plasma miR-21 is a novel diagnostic biomarker for biliary tract cancer. Cancer Sci. 2013, 104, 1626-1631. [CrossRef] [PubMed]

31. Rakic, M.; Patrlj, L.; Kopljar, M.; Klicek, R.; Kolovrat, M.; Loncar, B.; Busic, Z. Gallbladder cancer. Hepatobiliary Surg. Nutr. 2014, 3, 221-226. [PubMed] 
32. Misra, S.; Chaturvedi, A.; Misra, N.C.; Sharma, I.D. Carcinoma of the gallbladder. Lancet Oncol. 2003, 4, 167-176. [CrossRef]

33. Soto, S.; Herrera, H.; Rosas, C.; Lilayú, D. Cáncer de vesícula biliar durante el trienio 2001-2003 en el hospital base de osorno. Cuadernos de cirugia UACH 2004, 18, 21-26. [CrossRef]

34. Lazcano-Ponce, E.C.; Miquel, J.F.; Munoz, N.; Herrero, R.; Ferrecio, C.; Wistuba, I.I.; Alonso de Ruiz, P.; Aristi Urista, G.; Nervi, F. Epidemiology and molecular pathology of gallbladder cancer. CA Cancer J. Clin. 2001, 51, 349-364. [CrossRef] [PubMed]

35. Jarnagin, W.R.; Shoup, M. Surgical management of cholangiocarcinoma. Semin. Liver Dis. 2004, 24, 189-199. [CrossRef] [PubMed]

36. Malhi, H.; Gores, G.J. Cholangiocarcinoma: Modern advances in understanding a deadly old disease. J. Hepatol. 2006, 45, 856-867. [CrossRef] [PubMed]

37. Khan, S.A.; Thomas, H.C.; Davidson, B.R.; Taylor-Robinson, S.D. Cholangiocarcinoma. Lancet 2005, 366, 1303-1314. [CrossRef]

38. Blechacz, B.; Komuta, M.; Roskams, T.; Gores, G.J. Clinical diagnosis and staging of cholangiocarcinoma. Nat. Rev. Gastroenterol Hepatol. 2011, 8, 512-522. [CrossRef] [PubMed]

39. Cardinale, V.; Semeraro, R.; Torrice, A.; Gatto, M.; Napoli, C.; Bragazzi, M.C.; Gentile, R.; Alvaro, D. Intra-hepatic and extra-hepatic cholangiocarcinoma: New insight into epidemiology and risk factors. World J. Gastrointest. Oncol. 2010, 2, 407-416. [CrossRef] [PubMed]

40. Plieskatt, J.; Rinaldi, G.; Feng, Y.; Peng, J.; Easley, S.; Jia, X.; Potriquet, J.; Pairojkul, C.; Bhudhisawasdi, V.; Sripa, B.; et al. A microRNA profile associated with opisthorchis viverrini-induced cholangiocarcinoma in tissue and plasma. BMC Cancer 2015, 15. [CrossRef] [PubMed]

41. Perysinakis, I.; Margaris, I.; Kouraklis, G. Ampullary cancer-a separate clinical entity? Histopathology 2014, 64, 759-768. [CrossRef] [PubMed]

42. Ahn, D.H.; Bekaii-Saab, T. Ampullary cancer: An overview. Am. Soc. Clin. Oncol. Educ. Book 2014, 34, 112-115. [CrossRef] [PubMed]

43. Kala, Z.; Weber, P.; Hemmelova, B.; Marek, F.; Hlavsa, J.; Sobotka, M. Ampullary tumours (ampullomas) in the elderly - an interdisciplinary problem. Indian J. Med. Res. 2010, 131, 418-421. [PubMed]

44. Ito, F.; Agni, R.; Rettammel, R.J.; Been, M.J.; Cho, C.S.; Mahvi, D.M.; Rikkers, L.F.; Weber, S.M. Resection of hilar cholangiocarcinoma: Concomitant liver resection decreases hepatic recurrence. Ann. Surg. 2008, 248, 273-279. [CrossRef] [PubMed]

45. Kai, Z.S.; Pasquinelli, A.E. Microrna assassins: Factors that regulate the disappearance of miRNAs. Nat. Struct. Mol. Biol. 2010, 17, 5-10. [CrossRef] [PubMed]

46. Miller, G.; Jarnagin, W.R. Gallbladder carcinoma. Eur. J. Surg. Oncol. 2008, 34, 306-312. [CrossRef] [PubMed]

47. Mayo, S.C.; Shore, A.D.; Nathan, H.; Edil, B.; Wolfgang, C.L.; Hirose, K.; Herman, J.; Schulick, R.D.; Choti, M.A.; Pawlik, T.M. National trends in the management and survival of surgically managed gallbladder adenocarcinoma over 15 years: A population-based analysis. J.Gastrointest. Surg. 2010, 14, 1578-1591. [CrossRef] [PubMed]

48. Deshmukh, S.D.; Johnson, P.T.; Sheth, S.; Hruban, R.; Fishman, E.K. Ct of gallbladder cancer and its mimics: A pattern-based approach. Abdom. Imaging 2013, 38, 527-536. [CrossRef] [PubMed]

49. Kim, S.J.; Lee, J.M.; Lee, E.S.; Han, J.K.; Choi, B.I. Preoperative staging of gallbladder carcinoma using biliary $\mathrm{mr}$ imaging. J. Magn. Reson. Imaging JMRI 2015, 41, 314-321. [CrossRef] [PubMed]

50. Chen, C.Z.; Li, L.; Lodish, H.F.; Bartel, D.P. Micrornas modulate hematopoietic lineage differentiation. Science 2004, 303, 83-86. [CrossRef] [PubMed]

51. Croce, C.M.; Calin, G.A. MiRNAs, cancer, and stem cell division. Cell 2005, 122, 6-7. [CrossRef] [PubMed]

52. Zhang, B.; Pan, X.; Cobb, G.P.; Anderson, T.A. Micrornas as oncogenes and tumor suppressors. Dev. Biol. 2007, 302, 1-12. [CrossRef] [PubMed]

53. Garzon, R.; Fabbri, M.; Cimmino, A.; Calin, G.A.; Croce, C.M. MicroRNA expression and function in cancer. Trends Mol. Med. 2006, 12, 580-587. [CrossRef] [PubMed]

54. Cho, W.C. Oncomirs: The discovery and progress of microRNAs in cancers. Mol. Cancer 2007, 6, 60. [CrossRef] [PubMed]

55. Bandres, E.; Cubedo, E.; Agirre, X.; Malumbres, R.; Zarate, R.; Ramirez, N.; Abajo, A.; Navarro, A.; Moreno, I.; Monzo, M.; et al. Identification by real-time PCR of 13 mature microRNAs differentially expressed in colorectal cancer and non-tumoral tissues. Mol. Cancer 2006, 5, 29. [CrossRef] [PubMed] 
56. Hwang, J.H.; Voortman, J.; Giovannetti, E.; Steinberg, S.M.; Leon, L.G.; Kim, Y.T.; Funel, N.; Park, J.K.; Kim, M.A.; Kang, G.H.; et al. Identification of microRNA-21 as a biomarker for chemoresistance and clinical outcome following adjuvant therapy in resectable pancreatic cancer. PLoS ONE 2010, 5, e10630. [CrossRef] [PubMed]

57. Shinozaki, A.; Sakatani, T.; Ushiku, T.; Hino, R.; Isogai, M.; Ishikawa, S.; Uozaki, H.; Takada, K.; Fukayama, M. Downregulation of microRNA-200 in ebv-associated gastric carcinoma. Cancer Res. 2010, 70, 4719-4727. [CrossRef] [PubMed]

58. Zhou, M.; Liu, Z.; Zhao, Y.; Ding, Y.; Liu, H.; Xi, Y.; Xiong, W.; Li, G.; Lu, J.; Fodstad, O.; et al. MicroRNA-125b confers the resistance of breast cancer cells to paclitaxel through suppression of pro-apoptotic Bcl-2 antagonist killer 1 (Bak1). J. Biol. Chem. 2010, 285, 21496-21507. [CrossRef] [PubMed]

59. Lee, Y.; Ahn, C.; Han, J.; Choi, H.; Kim, J.; Yim, J.; Lee, J.; Provost, P.; Radmark, O.; Kim, S.; et al. The nuclear rnase iii drosha initiates microRNA processing. Nature 2003, 425, 415-419. [CrossRef] [PubMed]

60. Lee, Y.; Kim, M.; Han, J.; Yeom, K.H.; Lee, S.; Baek, S.H.; Kim, V.N. MicroRNA genes are transcribed by RNA polymerase II. EMBO J. 2004, 23, 4051-4060. [CrossRef] [PubMed]

61. Borchert, G.M.; Lanier, W.; Davidson, B.L. RNA polymerase iii transcribes human microRNAs. Nat. Struct Mol. Biol. 2006, 13, 1097-1101. [CrossRef] [PubMed]

62. Lee, Y.; Jeon, K.; Lee, J.T.; Kim, S.; Kim, V.N. MicroRNA maturation: Stepwise processing and subcellular localization. EMBO J. 2002, 21, 4663-4670. [CrossRef] [PubMed]

63. Calin, G.A.; Croce, C.M. MicroRNA signatures in human cancers. Nat. Rev. Cancer 2006, 6, 857-866. [CrossRef] [PubMed]

64. Cai, X.; Hagedorn, C.H.; Cullen, B.R. Human microRNAs are processed from capped, polyadenylated transcripts that can also function as mRNAs. RNA 2004, 10, 1957-1966. [CrossRef] [PubMed]

65. Ozsolak, F.; Poling, L.L.; Wang, Z.; Liu, H.; Liu, X.S.; Roeder, R.G.; Zhang, X.; Song, J.S.; Fisher, D.E. Chromatin structure analyses identify miRNA promoters. Genes Dev. 2008, 22, 3172-3183. [CrossRef] [PubMed]

66. Farazi, T.A.; Hoell, J.I.; Morozov, P.; Tuschl, T. MicroRNAs in human cancer. Adv. Exp. Med. Biol 2013, 774, 1-20. [PubMed]

67. Filippov, V.; Solovyev, V.; Filippova, M.; Gill, S.S. A novel type of RNAse iii family proteins in eukaryotes. Gene 2000, 245, 213-221. [CrossRef]

68. Bohnsack, M.T.; Czaplinski, K.; Gorlich, D. Exportin 5 is a RanGTP-dependent dsRNA-binding protein that mediates nuclear export of pre-miRNAs. RNA 2004, 10, 185-191. [CrossRef] [PubMed]

69. Lau, P.W.; Guiley, K.Z.; De, N.; Potter, C.S.; Carragher, B.; MacRae, I.J. The molecular architecture of human dicer. Nat. Struct. Mol. Biol. 2013, 19, 436-440. [CrossRef] [PubMed]

70. Lau, P.W.; MacRae, I.J. The molecular machines that mediate microRNA maturation. J. Cell. Mol. Med. 2009, 13, 54-60. [CrossRef] [PubMed]

71. Kim, V.N.; Han, J.; Siomi, M.C. Biogenesis of small RNAs in animals. Nat. Rev. Mol. Cell Biol 2009, 10, 126-139. [CrossRef] [PubMed]

72. Kawamata, T.; Seitz, H.; Tomari, Y. Structural determinants of miRNAs for risc loading and slicer-independent unwinding. Nat. Struct. Mol. Biol 2009, 16, 953-960. [CrossRef] [PubMed]

73. Westholm, J.O.; Lai, E.C. Mirtrons: MicroRNA biogenesis via splicing. Biochimie 2011, 93, 1897-1904. [CrossRef] [PubMed]

74. Yang, J.S.; Maurin, T.; Robine, N.; Rasmussen, K.D.; Jeffrey, K.L.; Chandwani, R.; Papapetrou, E.P.; Sadelain, M.; O'Carroll, D.; Lai, E.C. Conserved vertebrate miR-451 provides a platform for dicer-independent, ago2-mediated microRNA biogenesis. Proc. Natl. Acad. Sci. USA 2010, 107, 15163-15168. [CrossRef] [PubMed]

75. Berezikov, E.; Chung, W.J.; Willis, J.; Cuppen, E.; Lai, E.C. Mammalian mirtron genes. Mol. Cell 2007, 28, 328-336. [CrossRef] [PubMed]

76. Xie, M.; Steitz, J.A. Versatile microRNA biogenesis in animals and their viruses. RNA Biol. 2014, 11, 673-681. [CrossRef] [PubMed]

77. Liu, J.; Valencia-Sanchez, M.A.; Hannon, G.J.; Parker, R. MicroRNA-dependent localization of targeted mrnas to mammalian p-bodies. Nat. Cell Biol. 2005, 7,719-723. [CrossRef] [PubMed]

78. Lytle, J.R.; Yario, T.A.; Steitz, J.A. Target mRNAs are repressed as efficiently by microRNA-binding sites in the $5^{\prime}$ Utr as in the $3^{\prime}$ UTR. Proc. Natl. Acad. Sci. USA 2007, 104, 9667-9672. [CrossRef] [PubMed] 
79. Duursma, A.M.; Kedde, M.; Schrier, M.; le Sage, C.; Agami, R. miR-148 targets human dnmt3b protein coding region. RNA 2008, 14, 872-877. [CrossRef] [PubMed]

80. Gu, S.; Jin, L.; Zhang, F.; Sarnow, P.; Kay, M.A. Biological basis for restriction of microRNA targets to the $3^{\prime}$ untranslated region in mammalian mrnas. Nat. Struct. Mol. Biol. 2009, 16, 144-150. [CrossRef] [PubMed]

81. Lewis, B.P.; Burge, C.B.; Bartel, D.P. Conserved seed pairing, often flanked by adenosines, indicates that thousands of human genes are microRNA targets. Cell 2005, 120, 15-20. [CrossRef] [PubMed]

82. Brodersen, P.; Voinnet, O. Revisiting the principles of microRNA target recognition and mode of action. Nat. Rev. Mol. Cell Biol. 2009, 10, 141-148. [CrossRef] [PubMed]

83. Long, D.; Lee, R.; Williams, P.; Chan, C.Y.; Ambros, V.; Ding, Y. Potent effect of target structure on microRNA function. Nat. Struct. Mol. Biol. 2007, 14, 287-294. [CrossRef] [PubMed]

84. Eulalio, A.; Behm-Ansmant, I.; Izaurralde, E. P bodies: At the crossroads of post-transcriptional pathways. Nat. Rev. Mol. Cell Biol. 2007, 8, 9-22. [CrossRef] [PubMed]

85. Bartel, D.P. Micrornas: Genomics, biogenesis, mechanism, and function. Cell 2004, 116, 281-297. [CrossRef]

86. Ding, X.C.; Weiler, J.; Grosshans, H. Regulating the regulators: Mechanisms controlling the maturation of microRNAs. Trends Biotechnol. 2009, 27, 27-36. [CrossRef] [PubMed]

87. Calin, G.A.; Sevignani, C.; Dumitru, C.D.; Hyslop, T.; Noch, E.; Yendamuri, S.; Shimizu, M.; Rattan, S.; Bullrich, F.; Negrini, M.; et al. Human microRNA genes are frequently located at fragile sites and genomic regions involved in cancers. Proc. Natl. Acad. Sci. USA 2004, 101, 2999-3004. [CrossRef] [PubMed]

88. Jay, C.; Nemunaitis, J.; Chen, P.; Fulgham, P.; Tong, A.W. MiRNA profiling for diagnosis and prognosis of human cancer. DNA Cell Biol. 2007, 26, 293-300. [CrossRef] [PubMed]

89. Lujambio, A.; Esteller, M. CPG island hypermethylation of tumor suppressor microRNAs in human cancer. Cell Cycle 2007, 6, 1455-1459. [CrossRef] [PubMed]

90. Davis-Dusenbery, B.N.; Hata, A. Mechanisms of control of microRNA biogenesis. J. Biochem. 2010, 148, 381-392. [PubMed]

91. Han, L.; Witmer, P.D.; Casey, E.; Valle, D.; Sukumar, S. DNA methylation regulates microRNA expression. Cancer Biol. Ther. 2007, 6, 1284-1288. [CrossRef] [PubMed]

92. Hudson, R.S.; Yi, M.; Esposito, D.; Watkins, S.K.; Hurwitz, A.A.; Yfantis, H.G.; Lee, D.H.; Borin, J.F.; Naslund, M.J.; Alexander, R.B.; et al. MicroRNA-1 is a candidate tumor suppressor and prognostic marker in human prostate cancer. Nucleic Acids Res. 2011, 40, 3689-3703. [CrossRef] [PubMed]

93. Datta, J.; Kutay, H.; Nasser, M.W.; Nuovo, G.J.; Wang, B.; Majumder, S.; Liu, C.G.; Volinia, S.; Croce, C.M.; Schmittgen, T.D.; et al. Methylation mediated silencing of microRNA-1 gene and its role in hepatocellular carcinogenesis. Cancer Res. 2008, 68, 5049-5058. [CrossRef] [PubMed]

94. Suzuki, H.; Takatsuka, S.; Akashi, H.; Yamamoto, E.; Nojima, M.; Maruyama, R.; Kai, M.; Yamano, H.O.; Sasaki, Y.; Tokino, T.; et al. Genome-wide profiling of chromatin signatures reveals epigenetic regulation of microRNA genes in colorectal cancer. Cancer Res. 2011, 71, 5646-5658. [CrossRef] [PubMed]

95. Krzeminski, P.; Sarasquete, M.E.; Misiewicz-Krzeminska, I.; Corral, R.; Corchete, L.A.; Martin, A.A.; Garcia-Sanz, R.; San Miguel, J.F.; Gutierrez, N.C. Insights into epigenetic regulation of microRNA-155 expression in multiple myeloma. Biochim. Biophys. Acta 2014, 1849, 353-366. [CrossRef] [PubMed]

96. Dakhlallah, D.; Batte, K.; Wang, Y.; Cantemir-Stone, C.Z.; Yan, P.; Nuovo, G.; Mikhail, A.; Hitchcock, C.L.; Wright, V.P.; Nana-Sinkam, S.P.; et al. Epigenetic regulation of miR-17 92 contributes to the pathogenesis of pulmonary fibrosis. Am. J. Respir. Crit. Care Med. 2013, 187, 397-405. [CrossRef] [PubMed]

97. Thomson, J.M.; Newman, M.; Parker, J.S.; Morin-Kensicki, E.M.; Wright, T.; Hammond, S.M. Extensive post-transcriptional regulation of microRNAs and its implications for cancer. Genes Dev. 2006, 20, 2202-2207. [CrossRef] [PubMed]

98. Karube, Y.; Tanaka, H.; Osada, H.; Tomida, S.; Tatematsu, Y.; Yanagisawa, K.; Yatabe, Y.; Takamizawa, J.; Miyoshi, S.; Mitsudomi, T.; et al. Reduced expression of dicer associated with poor prognosis in lung cancer patients. Cancer Sci. 2005, 96, 111-115. [CrossRef] [PubMed]

99. Zhu, D.X.; Fan, L.; Lu, R.N.; Fang, C.; Shen, W.Y.; Zou, Z.J.; Wang, Y.H.; Zhu, H.Y.; Miao, K.R.; Liu, P.; et al. Downregulated dicer expression predicts poor prognosis in chronic lymphocytic leukemia. Cancer Sci. 2012, 103, 875-881. [CrossRef] [PubMed]

100. Gillies, J.K.; Lorimer, I.A. Regulation of p27kip1 by miRNA 221/222 in glioblastoma. Cell Cycle 2007, 6, 2005-2009. [CrossRef] [PubMed] 
101. Hill, D.A.; Ivanovich, J.; Priest, J.R.; Gurnett, C.A.; Dehner, L.P.; Desruisseau, D.; Jarzembowski, J.A.; Wikenheiser-Brokamp, K.A.; Suarez, B.K.; Whelan, A.J.; et al. Dicer1 mutations in familial pleuropulmonary blastoma. Science 2009, 325, 965. [CrossRef] [PubMed]

102. Macfarlane, L.A.; Murphy, P.R. MicroRNA: Biogenesis, function and role in cancer. Curr. Genom. 2010, 11, 537-561. [CrossRef] [PubMed]

103. Davis, C.D.; Ross, S.A. Evidence for dietary regulation of microRNA expression in cancer cells. Nutr. Rev. 2008, 66, 477-482. [CrossRef] [PubMed]

104. Fiedler, S.D.; Carletti, M.Z.; Hong, X.; Christenson, L.K. Hormonal regulation of microRNA expression in periovulatory mouse mural granulosa cells. Biol. Reprod. 2008, 79, 1030-1037. [CrossRef] [PubMed]

105. Kulshreshtha, R.; Ferracin, M.; Negrini, M.; Calin, G.A.; Davuluri, R.V.; Ivan, M. Regulation of microRNA expression: The hypoxic component. Cell Cycle 2007, 6, 1426-1431. [CrossRef] [PubMed]

106. Moldovan, L.; Batte, K.E.; Trgovcich, J.; Wisler, J.; Marsh, C.B.; Piper, M. Methodological challenges in utilizing miRNAs as circulating biomarkers. J. Cell. Mol. Med. 2014, 18, 371-390. [CrossRef] [PubMed]

107. Xu, Y.; Bu, X.; Dai, C.; Shang, C. High serum microRNA-122 level is independently associated with higher overall survival rate in hepatocellular carcinoma patients. Tumour Biol. 2015, 36, 4773-4776. [CrossRef] [PubMed]

108. Yanez-Mo, M.; Siljander, P.R.; Andreu, Z.; Zavec, A.B.; Borras, F.E.; Buzas, E.I.; Buzas, K.; Casal, E.; Cappello, F.; Carvalho, J.; et al. Biological properties of extracellular vesicles and their physiological functions. J. Extracell. Vesicles 2015, 4, 27066. [PubMed]

109. Sun, T.; Kalionis, B.; Lv, G.; Xia, S.; Gao, W. Role of exosomal noncoding rnas in lung carcinogenesis. BioMed Res. Int. 2015, 2015, 125807. [CrossRef] [PubMed]

110. Valadi, H.; Ekstrom, K.; Bossios, A.; Sjostrand, M.; Lee, J.J.; Lotvall, J.O. Exosome-mediated transfer of mrnas and microRNAs is a novel mechanism of genetic exchange between cells. Nat. Cell Biol. 2007, 9, 654-659. [CrossRef] [PubMed]

111. Yuan, A.; Farber, E.L.; Rapoport, A.L.; Tejada, D.; Deniskin, R.; Akhmedov, N.B.; Farber, D.B. Transfer of microRNAs by embryonic stem cell microvesicles. PLoS ONE 2009, 4, e4722. [CrossRef] [PubMed]

112. Ratajczak, J.; Miekus, K.; Kucia, M.; Zhang, J.; Reca, R.; Dvorak, P.; Ratajczak, M.Z. Embryonic stem cell-derived microvesicles reprogram hematopoietic progenitors: Evidence for horizontal transfer of mrna and protein delivery. Leukemia 2006, 20, 847-856. [CrossRef] [PubMed]

113. Khoury, S.; Tran, N. Circulating microRNAs: Potential biomarkers for common malignancies. Biomark. Med. 2009, 9, 131-151. [CrossRef] [PubMed]

114. Shigehara, K.; Yokomuro, S.; Ishibashi, O.; Mizuguchi, Y.; Arima, Y.; Kawahigashi, Y.; Kanda, T.; Akagi, I.; Tajiri, T.; Yoshida, H.; et al. Real-time pcr-based analysis of the human bile microRNAome identifies miR-9 as a potential diagnostic biomarker for biliary tract cancer. PLoS ONE 2011, 6, e23584. [CrossRef] [PubMed]

115. Caby, M.P.; Lankar, D.; Vincendeau-Scherrer, C.; Raposo, G.; Bonnerot, C. Exosomal-like vesicles are present in human blood plasma. Int. Immunol. 2005, 17, 879-887. [CrossRef] [PubMed]

116. Ren, Y.; Yang, J.; Xie, R.; Gao, L.; Yang, Y.; Fan, H.; Qian, K. Exosomal-like vesicles with immune-modulatory features are present in human plasma and can induce CD4 ${ }^{+}$T-cell apoptosis in vitro. Transfusion 2011, 51, 1002-1011. [CrossRef] [PubMed]

117. Yuan, T.; Huang, X.; Woodcock, M.; Du, M.; Dittmar, R.; Wang, Y.; Tsai, S.; Kohli, M.; Boardman, L.; Patel, T.; et al. Plasma extracellular rna profiles in healthy and cancer patients. Sci. Rep. 2016, 6. [CrossRef] [PubMed]

118. Villarroya-Beltri, C.; Gutierrez-Vazquez, C.; Sanchez-Cabo, F.; Perez-Hernandez, D.; Vazquez, J.; Martin-Cofreces, N.; Martinez-Herrera, D.J.; Pascual-Montano, A.; Mittelbrunn, M.; Sanchez-Madrid, F. Sumoylated hnRNPA2B1 controls the sorting of miRNAs into exosomes through binding to specific motifs. Nat. Commun. 2013, 4, 2980. [CrossRef] [PubMed]

119. Koppers-Lalic, D.; Hackenberg, M.; Bijnsdorp, I.V.; van Eijndhoven, M.A.; Sadek, P.; Sie, D.; Zini, N.; Middeldorp, J.M.; Ylstra, B.; de Menezes, R.X.; et al. Nontemplated nucleotide additions distinguish the small rna composition in cells from exosomes. Cell Rep. 2014, 8, 1649-1658. [CrossRef] [PubMed]

120. Creemers, E.E.; Tijsen, A.J.; Pinto, Y.M. Circulating microRNAs: Novel biomarkers and extracellular communicators in cardiovascular disease? Circ. Res. 2012, 110, 483-495. [CrossRef] [PubMed]

121. Fernandez-Messina, L.; Gutierrez-Vazquez, C.; Rivas-Garcia, E.; Sanchez-Madrid, F.; de la Fuente, H. Immunomodulatory role of microRNAs transferred by extracellular vesicles. Biol. Cell 2015, 107, 61-77. [CrossRef] [PubMed] 
122. de Candia, P.; Torri, A.; Gorletta, T.; Fedeli, M.; Bulgheroni, E.; Cheroni, C.; Marabita, F.; Crosti, M.; Moro, M.; Pariani, E.; et al. Intracellular modulation, extracellular disposal and serum increase of miR-150 mark lymphocyte activation. PLoS ONE 2013, 8, e75348. [CrossRef] [PubMed]

123. Ostenfeld, M.S.; Jeppesen, D.K.; Laurberg, J.R.; Boysen, A.T.; Bramsen, J.B.; Primdal-Bengtson, B.; Hendrix, A.; Lamy, P.; Dagnaes-Hansen, F.; Rasmussen, M.H.; et al. Cellular disposal of mir23b by rab27-dependent exosome release is linked to acquisition of metastatic properties. Cancer Res. 2014, 74, 5758-5771. [CrossRef] [PubMed]

124. Hunter, M.P.; Ismail, N.; Zhang, X.; Aguda, B.D.; Lee, E.J.; Yu, L.; Xiao, T.; Schafer, J.; Lee, M.L.; Schmittgen, T.D; i et al. Detection of microRNA expression in human peripheral blood microvesicles. PLOS ONE 2008, 3, e3694. [CrossRef] [PubMed]

125. Wang, K.; Zhang, S.; Weber, J.; Baxter, D.; Galas, D.J. Export of microRNAs and microRNA-protective protein by mammalian cells. Nucleic Acids Res. 2010, 38, 7248-7259. [CrossRef] [PubMed]

126. Arroyo, J.D.; Chevillet, J.R.; Kroh, E.M.; Ruf, I.K.; Pritchard, C.C.; Gibson, D.F.; Mitchell, P.S.; Bennett, C.F.; Pogosova-Agadjanyan, E.L.; Stirewalt, D.L.; et al. Argonaute2 complexes carry a population of circulating microRNAs independent of vesicles in human plasma. Proc. Natl. Acad. Sci. USA 2011, 108, 5003-5008. [CrossRef] [PubMed]

127. Turchinovich, A.; Weiz, L.; Langheinz, A.; Burwinkel, B. Characterization of extracellular circulating microRNA. Nucleic Acids Res. 2011, 39, 7223-7233. [CrossRef] [PubMed]

128. Zernecke, A.; Bidzhekov, K.; Noels, H.; Shagdarsuren, E.; Gan, L.; Denecke, B.; Hristov, M.; Koppel, T.; Jahantigh, M.N.; Lutgens, E.; et al. Delivery of microRNA-126 by apoptotic bodies induces cxcl12-dependent vascular protection. Sci. Signal. 2009, 2, ra81. [CrossRef] [PubMed]

129. Vickers, K.C.; Palmisano, B.T.; Shoucri, B.M.; Shamburek, R.D.; Remaley, A.T. MicroRNAs are transported in plasma and delivered to recipient cells by high-density lipoproteins. Nat. Cell Biol. 2011, 13, 423-433. [CrossRef] [PubMed]

130. Wagner, J.; Riwanto, M.; Besler, C.; Knau, A.; Fichtlscherer, S.; Roxe, T.; Zeiher, A.M.; Landmesser, U.; Dimmeler, S. Characterization of levels and cellular transfer of circulating lipoprotein-bound microRNAs. Arterioscler. Thromb. Vasc. Biol. 2013, 33, 1392-1400. [CrossRef] [PubMed]

131. Meng, F.; Henson, R.; Lang, M.; Wehbe, H.; Maheshwari, S.; Mendell, J.T.; Jiang, J.; Schmittgen, T.D.; Patel, T. Involvement of human micro-RNA in growth and response to chemotherapy in human cholangiocarcinoma cell lines. Gastroenterology 2006, 130, 2113-2129. [CrossRef] [PubMed]

132. Li, G.; Pu, Y. MicroRNA signatures in total peripheral blood of gallbladder cancer patients. Tumour Biol. 2015, 36, 6985-6990. [CrossRef] [PubMed]

133. Chen, L.; Yan, H.X.; Yang, W.; Hu, L.; Yu, L.X.; Liu, Q.; Li, L.; Huang, D.D.; Ding, J.; Shen, F.; et al. The role of microRNA expression pattern in human intrahepatic cholangiocarcinoma. J. Hepatol. 2009, 50, 358-369. [CrossRef] [PubMed]

134. Wang, S.; Yin, J.; Li, T.; Yuan, L.; Wang, D.; He, J.; Du, X.; Lu, J. Upregulated circulating miR-150 is associated with the risk of intrahepatic cholangiocarcinoma. Oncol. Rep. 2015, 33, 819-825. [CrossRef] [PubMed]

135. Silakit, R.; Loilome, W.; Yongvanit, P.; Chusorn, P.; Techasen, A.; Boonmars, T.; Khuntikeo, N.; Chamadol, N.; Pairojkul, C.; Namwat, N. Circulating miR-192 in liver fluke-associated cholangiocarcinoma patients: A prospective prognostic indicator. J. Hepatobiliary Pancreat. Sci. 2014, 21, 864-872. [CrossRef] [PubMed]

136. Voigtlander, T.; Gupta, S.K.; Thum, S.; Fendrich, J.; Manns, M.P.; Lankisch, T.O.; Thum, T. Micrornas in serum and bile of patients with primary sclerosing cholangitis and/or cholangiocarcinoma. PLoS ONE 2015, 10, e0139305. [CrossRef] [PubMed]

137. Bernuzzi, F.; Marabita, F.; Lleo, A.; Carbone, M.; Mirolo, M.; Marzioni, M.; Alpini, G.; Alvaro, D.; Muri Boberg, K.; Locati, M.; et al. Serum microRNAs as novel biomarkers for primary sclerosing cholangitis and cholangiocarcinoma. Clin. Exp. Immunol. 2016. [CrossRef] [PubMed]

138. Kojima, M.; Sudo, H.; Kawauchi, J.; Takizawa, S.; Kondou, S.; Nobumasa, H.; Ochiai, A. MicroRNA markers for the diagnosis of pancreatic and biliary-tract cancers. PLOS ONE 2015, 10, e0118220. [CrossRef] [PubMed]

139. Cheng, Q.; Feng, F.; Zhu, L.; Zheng, Y.; Luo, X.; Liu, C.; Yi, B.; Jiang, X. Circulating miR-106a is a novel prognostic and lymph node metastasis indicator for cholangiocarcinoma. Sci. Rep. 2015, 5, 16103. [CrossRef] [PubMed] 
140. Huang, S.; Chen, Y.; Wu, W.; Ouyang, N.; Chen, J.; Li, H.; Liu, X.; Su, F.; Lin, L.; Yao, Y. miR-150 promotes human breast cancer growth and malignant behavior by targeting the pro-apoptotic purinergic $\mathrm{P} 2 \mathrm{X} 7$ receptor. PLoS ONE 2013, 8, e80707. [CrossRef] [PubMed]

141. Wu, Q.; Jin, H.; Yang, Z.; Luo, G.; Lu, Y.; Li, K.; Ren, G.; Su, T.; Pan, Y.; Feng, B.; et al. miR-150 promotes gastric cancer proliferation by negatively regulating the pro-apoptotic gene egr2. Biochem. Biophys. Res. Commun. 2010, 392, 340-345. [CrossRef] [PubMed]

142. Feng, J.; Yang, Y.; Zhang, P.; Wang, F.; Ma, Y.; Qin, H.; Wang, Y. miR-150 functions as a tumour suppressor in human colorectal cancer by targeting c-myb. J. Cell. Mol. Med. 2014, 18, 2125-2134. [CrossRef] [PubMed]

143. Qu, Y.; Pan, S.; Kang, M.; Dong, R.; Zhao, J. MicroRNA-150 functions as a tumor suppressor in osteosarcoma by targeting IGF2BP1. Tumour Biol. 2016, 37, 5275-5284. [CrossRef] [PubMed]

144. Huang, M.; Wu, X.; Cao, H.; Zhan, Q.; Xia, M.; Zhou, Q.; Cai, X.; An, F. Regulatory role of serum miR-224 in invasiveness and metastasis of cholangiocarcinoma. Zhonghua Gan Zang Bing Za Zhi 2015, 23, 748-753. (In Chinese) [PubMed]

145. Que, R.; Ding, G.; Chen, J.; Cao, L. Analysis of serum exosomal microRNAs and clinicopathologic features of patients with pancreatic adenocarcinoma. World J. Surg. Oncol. 2013, 11, 219. [CrossRef] [PubMed]

146. Pasternak, A.; Szura, M.; Gil, K.; Brzozowska, I.; Maduzia, D.; Mizia, E.; Walocha, K.; Matyja, A. Metabolism of bile with respect to etiology of gallstone disease-Systematic review. Folia Med. Cracov. 2014, 54, 5-16. [PubMed]

147. Munoz-Garrido, P.; Garcia-Fernandez de Barrena, M.; Hijona, E.; Carracedo, M.; Marin, J.J.; Bujanda, L.; Banales, J.M. Micrornas in biliary diseases. World J. Gastroenterol. 2012, 18, 6189-6196. [CrossRef] [PubMed]

148. Haga, H.; Yan, I.; Takahashi, K.; Wood, J.; Patel, T. Emerging insights into the role of microRNAs in the pathogenesis of cholangiocarcinoma. Gene Expr. 2014, 16, 93-99. [CrossRef] [PubMed]

149. Seo, N.; Kim, S.Y.; Lee, S.S.; Byun, J.H.; Kim, J.H.; Kim, H.J.; Lee, M.G. Sclerosing cholangitis: Clinicopathologic features, imaging spectrum, and systemic approach to differential diagnosis. Korean J. Radiol. 2016, 17, 25-38. [CrossRef] [PubMed]

150. Hundal, R.; Shaffer, E.A. Gallbladder cancer: Epidemiology and outcome. Clin. Epidemiol. 2014, 6, 99-109. [PubMed]

151. Lamont, J.T.; Carey, M.C. Cholesterol gallstone formation. 2. Pathobiology and pathomechanics. Prog. Liver Dis. 1992, 10, 165-191. [PubMed]

152. Yang, B.; Liu, B.; Bi, P.; Wu, T.; Wang, Q.; Zhang, J. An integrated analysis of differential miRNA and mRNA expressions in human gallstones. Mol. Biosyst. 2015, 11, 1004-1011. [CrossRef] [PubMed]

153. Fanyin Meng, H.F.; Han, Y.; Glaser, S.; Alpini, G. Functional role of microRNA-200 family in human gall bladder cancer stem cells. FASEB J. 2015, 29 (Suppl. 45), 45-47.

154. Xiao, Y.; Wang, J.; Yan, W.; Zhou, Y.; Chen, Y.; Zhou, K.; Wen, J.; Wang, Y.; Cai, W. Dysregulated miR-124 and miR-200 expression contribute to cholangiocyte proliferation in the cholestatic liver by targeting il-6/stat3 signalling. J. Hepatol. 2014, 62, 889-896. [CrossRef] [PubMed]

155. Zahm, A.M.; Hand, N.J.; Boateng, L.A.; Friedman, J.R. Circulating microRNA is a biomarker of biliary atresia. J. Pediatr. Gastroenterol. Nutr. 2012, 55, 366-369. [CrossRef] [PubMed]

156. Lee, J.; Kemper, J.K. Controlling sirt1 expression by microRNAs in health and metabolic disease. Aging (Albany NY) 2010, 2, 527-534. [CrossRef] [PubMed]

157. Gadaleta, R.M.; van Mil, S.W.; Oldenburg, B.; Siersema, P.D.; Klomp, L.W.; van Erpecum, K.J. Bile acids and their nuclear receptor FXR: Relevance for hepatobiliary and gastrointestinal disease. Biochim. Biophys Acta 2010, 1801, 683-692. [CrossRef] [PubMed]

158. Tarling, E.J.; Ahn, H.; de Aguiar Vallim, T.Q. The nuclear receptor FXR uncouples the actions of miR-33 from srebp-2. Arterioscler. Thromb. Vasc. Biol. 2015, 35, 787-795. [CrossRef] [PubMed]

159. Allen, R.M.; Marquart, T.J.; Albert, C.J.; Suchy, F.J.; Wang, D.Q.; Ananthanarayanan, M.; Ford, D.A.; Baldan, A. miR-33 controls the expression of biliary transporters, and mediates statin- and diet-induced hepatotoxicity. EMBO Mol. Med. 2012, 4, 882-895. [CrossRef] [PubMed]

160. de Aguiar Vallim, T.Q.; Tarling, E.J.; Kim, T.; Civelek, M.; Baldan, A.; Esau, C.; Edwards, P.A. Microrna-144 regulates hepatic atp binding cassette transporter a1 and plasma high-density lipoprotein after activation of the nuclear receptor farnesoid $x$ receptor. Circ. Res. 2013, 112, 1602-1612. [CrossRef] [PubMed]

161. Song, K.H.; Li, T.; Owsley, E.; Chiang, J.Y. A putative role of microRNA in regulation of cholesterol $7 \alpha$-hydroxylase expression in human hepatocytes. J. Lipid Res. 2010, 51, 2223-2233. [CrossRef] [PubMed] 
162. Esau, C.; Davis, S.; Murray, S.F.; Yu, X.X.; Pandey, S.K.; Pear, M.; Watts, L.; Booten, S.L.; Graham, M.; McKay, R.; et al. miR-122 regulation of lipid metabolism revealed by in vivo antisense targeting. Cell Metab. 2006, 3, 87-98. [CrossRef] [PubMed]

163. Iliopoulos, D.; Drosatos, K.; Hiyama, Y.; Goldberg, I.J.; Zannis, V.I. MicroRNA-370 controls the expression of microRNA-122 and cpt1alpha and affects lipid metabolism. J. Lipid Res. 2010, 51, 1513-1523. [CrossRef] [PubMed]

164. Gerin, I.; Bommer, G.T.; McCoin, C.S.; Sousa, K.M.; Krishnan, V.; MacDougald, O.A. Roles for miRNA-378/378* in adipocyte gene expression and lipogenesis. Am. J. Physiol. Endocrinol. Metab. 2010, 299, E198-E206. [CrossRef] [PubMed]

165. Lin, Q.; Gao, Z.; Alarcon, R.M.; Ye, J.; Yun, Z. A role of miR-27 in the regulation of adipogenesis. FEBS J. 2009, 276, 2348-2358. [CrossRef] [PubMed]

166. Nakanishi, N.; Nakagawa, Y.; Tokushige, N.; Aoki, N.; Matsuzaka, T.; Ishii, K.; Yahagi, N.; Kobayashi, K.; Yatoh, S.; Takahashi, A.; et al. The up-regulation of microRNA-335 is associated with lipid metabolism in liver and white adipose tissue of genetically obese mice. Biochem. Biophys. Res. Commun. 2009, 385, 492-496. [CrossRef] [PubMed]

167. Rayner, K.J.; Suarez, Y.; Davalos, A.; Parathath, S.; Fitzgerald, M.L.; Tamehiro, N.; Fisher, E.A.; Moore, K.J.; Fernandez-Hernando, C. miR-33 contributes to the regulation of cholesterol homeostasis. Science 2010, 328, 1570-1573. [CrossRef] [PubMed]

168. Ono, K.; Horie, T.; Nishino, T.; Baba, O.; Kuwabara, Y.; Yokode, M.; Kita, T.; Kimura, T. Microrna-33a/b in lipid metabolism-Novel "Thrifty" Models. Circ. J. 2015, 79, 278-284. [CrossRef] [PubMed]

169. Alvarez, M.L.; Khosroheidari, M.; Eddy, E.; Done, S.C. MicroRNA-27a decreases the level and efficiency of the LDL receptor and contributes to the dysregulation of cholesterol homeostasis. Atherosclerosis 2015, 242, 595-604. [CrossRef] [PubMed]

170. Nishi, H.; Fisher, E.A. Cholesterol homeostasis regulation by miR-223: Basic science mechanisms and translational implications. Circ. Res. 2015, 116, 1112-1114. [CrossRef] [PubMed]

171. Chu, B.; Wu, T.; Miao, L.; Mei, Y.; Wu, M. miR-181a regulates lipid metabolism via IDH1. Sci. Rep. $2015,5$. [CrossRef] [PubMed]

172. Wang, X.C.; Zhan, X.R.; Li, X.Y.; Yu, J.J.; Liu, X.M. MicroRNA-185 regulates expression of lipid metabolism genes and improves insulin sensitivity in mice with non-alcoholic fatty liver disease. World J. Gastroenterol. 2014, 20, 17914-17923. [PubMed]

173. Vickers, K.C.; Landstreet, S.R.; Levin, M.G.; Shoucri, B.M.; Toth, C.L.; Taylor, R.C.; Palmisano, B.T.; Tabet, F.; Cui, H.L.; Rye, K.A.; et al. MicroRNA-223 coordinates cholesterol homeostasis. Proc. Natl. Acad. Sci. USA 2014, 111, 14518-14523. [CrossRef] [PubMed]

174. Stokes, C.S.; Krawczyk, M.; Lammert, F. Gallstones: Environment, lifestyle and genes. Dig. Dis. 2011, 29, 191-201. [CrossRef] [PubMed]

175. Di Ciaula, A.; Wang, D.Q.; Bonfrate, L.; Portincasa, P. Current views on genetics and epigenetics of cholesterol gallstone disease. Cholesterol 2013, 2013, 298421. [CrossRef] [PubMed]

176. Eiholm, S.; Thielsen, P.; Kromann-Andersen, H. Endoscopic brush cytology from the biliary duct system is still valuable. Dan Med. J. 2013, 60, A4656. [PubMed]

177. Kosaka, N.; Iguchi, H.; Ochiya, T. Circulating microRNA in body fluid: A new potential biomarker for cancer diagnosis and prognosis. Cancer Sci. 2010, 101, 2087-2092. [CrossRef]

178. Shen, J.; Stass, S.A.; Jiang, F. MicroRNAs as potential biomarkers in human solid tumors. Cancer Lett. 2013, 329, 125-136. [CrossRef] [PubMed]

179. Schwarzenbach, H.; Nishida, N.; Calin, G.A.; Pantel, K. Clinical relevance of circulating cell-free microRNAs in cancer. Nat. Rev. Clin. Oncol. 2014, 11, 145-156. [CrossRef] [PubMed]

180. Mitchell, P.S.; Parkin, R.K.; Kroh, E.M.; Fritz, B.R.; Wyman, S.K.; Pogosova-Agadjanyan, E.L.; Peterson, A.; Noteboom, J.; O'Briant, K.C.; Allen, A.; et al. Circulating microRNAs as stable blood-based markers for cancer detection. Proc. Natl. Acad. Sci. USA 2008, 105, 10513-10518. [CrossRef] [PubMed]

181. Lawrie, C.H.; Gal, S.; Dunlop, H.M.; Pushkaran, B.; Liggins, A.P.; Pulford, K.; Banham, A.H.; Pezzella, F.; Boultwood, J.; Wainscoat, J.S.; et al. Detection of elevated levels of tumour-associated microRNAs in serum of patients with diffuse large b-cell lymphoma. Br. J. Haematol. 2008, 141, 672-675. [CrossRef] [PubMed] 
182. Zhou, H.; Guo, W.; Zhao, Y.; Wang, Y.; Zha, R.; Ding, J.; Liang, L.; Hu, J.; Shen, H.; Chen, Z.; et al. MicroRNA-26a acts as a tumor suppressor inhibiting gallbladder cancer cell proliferation by directly targeting HMGA2. Int. J. Oncol. 2014, 44, 2050-2058. [CrossRef] [PubMed]

183. Zhou, H.; Guo, W.; Zhao, Y.; Wang, Y.; Zha, R.; Ding, J.; Liang, L.; Yang, G.; Chen, Z.; Ma, B.; et al. MicroRNA-135a acts as a putative tumor suppressor by directly targeting very low density lipoprotein receptor in human gallbladder cancer. Cancer Sci. 2014, 105, 956-965. [CrossRef] [PubMed]

184. Jin, K.; Xiang, Y.; Tang, J.; Wu, G.; Li, J.; Xiao, H.; Li, C.; Chen, Y.; Zhao, J. miR-34 is associated with poor prognosis of patients with gallbladder cancer through regulating telomere length in tumor stem cells. Tumour Biol. 2013, 35, 1503-1510. [CrossRef] [PubMed]

185. Peng, H.H.; Zhang, Y.D.; Gong, L.S.; Liu, W.D.; Zhang, Y. Increased expression of microRNA-335 predicts a favorable prognosis in primary gallbladder carcinoma. Onco. Targets Ther. 2013, 6, 1625-1630. [PubMed]

186. Ma, M.Z.; Li, C.X.; Zhang, Y.; Weng, M.Z.; Zhang, M.D.; Qin, Y.Y.; Gong, W.; Quan, Z.W. Long non-coding RNA hotair, a c-myc activated driver of malignancy, negatively regulates miRNA-130a in gallbladder cancer. Mol. Cancer 2014, 13, 156. [CrossRef] [PubMed]

187. Ma, M.Z.; Chu, B.F.; Zhang, Y.; Weng, M.Z.; Qin, Y.Y.; Gong, W.; Quan, Z.W. Long non-coding RNA CCAT1 promotes gallbladder cancer development via negative modulation of miRNA-218-5p. Cell. Death Dis. 2015, 6, e1583. [CrossRef] [PubMed]

188. Kono, H.; Nakamura, M.; Ohtsuka, T.; Nagayoshi, Y.; Mori, Y.; Takahata, S.; Aishima, S.; Tanaka, M. High expression of microRNA-155 is associated with the aggressive malignant behavior of gallbladder carcinoma. Oncol. Rep. 2013, 30, 17-24. [PubMed]

189. Chang, Y.; Liu, C.; Yang, J.; Liu, G.; Feng, F.; Tang, J.; Hu, L.; Li, L.; Jiang, F.; Chen, C.; et al. miR-20a triggers metastasis of gallbladder carcinoma. J. Hepatol. 2013, 59, 518-527. [CrossRef] [PubMed]

190. Qiu, Y.; Luo, X.; Kan, T.; Zhang, Y.; Yu, W.; Wei, Y.; Shen, N.; Yi, B.; Jiang, X. TGF- $\beta$ upregulates miR-182 expression to promote gallbladder cancer metastasis by targeting cadm1. Mol. Biosyst. 2014, 10, 679-685. [CrossRef] [PubMed]

191. Zhang, J.; Han, C.; Wu, T. MicroRNA-26a promotes cholangiocarcinoma growth by activating $\beta$-catenin. Gastroenterology 2012, 143, 246-256.e8. [CrossRef] [PubMed]

192. Chen, X.; Chen, J.; Liu, X.; Guo, Z.; Sun, X.; Zhang, J. The real-time dynamic monitoring of microRNA function in cholangiocarcinoma. PLoS ONE 2014, 9, e99431. [CrossRef] [PubMed]

193. Choi, D.H.; Park, S.J.; Kim, H.K. miR-215 overexpression distinguishes ampullary carcinomas from pancreatic carcinomas. Hepatobiliary Pancreat. Dis. Int. 2015, 14, 325-329. [CrossRef]

194. Witek, R.P.; Yang, L.; Liu, R.; Jung, Y.; Omenetti, A.; Syn, W.K.; Choi, S.S.; Cheong, Y.; Fearing, C.M.; Agboola, K.M.; et al. Liver cell-derived microparticles activate hedgehog signaling and alter gene expression in hepatic endothelial cells. Gastroenterology 2009, 136, 320-330.e2. [CrossRef] [PubMed]

195. Zhang, J.; Li, S.; Li, L.; Li, M.; Guo, C.; Yao, J.; Mi, S. Exosome and exosomal microRNA: Trafficking, sorting, and function. Genom. Proteom. Bioinform. 2015, 13, 17-24. [CrossRef] [PubMed]

196. Pigati, L.; Yaddanapudi, S.C.; Iyengar, R.; Kim, D.J.; Hearn, S.A.; Danforth, D.; Hastings, M.L.; Duelli, D.M. Selective release of microRNA species from normal and malignant mammary epithelial cells. PLoS ONE 2010, 5, e13515. [CrossRef] [PubMed]

197. Collins, A.L.; Wojcik, S.; Liu, J.; Frankel, W.L.; Alder, H.; Yu, L.; Schmittgen, T.D.; Croce, C.M.; Bloomston, M. A differential microRNA profile distinguishes cholangiocarcinoma from pancreatic adenocarcinoma. Ann. Surg. Oncol. 2014, 21, 133-138. [CrossRef] [PubMed]

198. Sekine, S.; Shimada, Y.; Nagata, T.; Sawada, S.; Yoshioka, I.; Matsui, K.; Moriyama, M.; Omura, T.; Osawa, S.; Shibuya, K.; et al. Role of aquaporin-5 in gallbladder carcinoma. Eur. Surg. Res. 2013, 51, 108-117. [CrossRef] [PubMed]

199. Paraskevi, A.; Theodoropoulos, G.; Papaconstantinou, I.; Mantzaris, G.; Nikiteas, N.; Gazouli, M. Circulating microRNA in inflammatory bowel disease. J. Crohns Colitis 2012, 6, 900-904. [CrossRef] [PubMed]

200. Sandanayake, N.S.; Sinclair, J.; Andreola, F.; Chapman, M.H.; Xue, A.; Webster, G.J.; Clarkson, A.; Gill, A.; Norton, I.D.; Smith, R.C.; et al. A combination of serum leucine-rich $\alpha$-2-glycoprotein 1, CA19-9 and interleukin-6 differentiate biliary tract cancer from benign biliary strictures. Br. J. Cancer 2011, 105, 1370-1378. [CrossRef] [PubMed] 
201. Xu, J.; Wu, C.; Che, X.; Wang, L.; Yu, D.; Zhang, T.; Huang, L.; Li, H.; Tan, W.; Wang, C.; et al. Circulating microRNAs, miR-21, miR-122, and miR-223, in patients with hepatocellular carcinoma or chronic hepatitis. Mol. Carcinog. 2011, 50, 136-142. [CrossRef] [PubMed]

202. Komatsu, S.; Ichikawa, D.; Takeshita, H.; Tsujiura, M.; Morimura, R.; Nagata, H.; Kosuga, T.; Iitaka, D.; Konishi, H.; Shiozaki, A.; et al. Circulating microRNAs in plasma of patients with oesophageal squamous cell carcinoma. Br. J. Cancer 2011, 105, 104-111. [CrossRef] [PubMed]

203. Zhang, H.L.; Yang, L.F.; Zhu, Y.; Yao, X.D.; Zhang, S.L.; Dai, B.; Zhu, Y.P.; Shen, Y.J.; Shi, G.H.; Ye, D.W. Serum miRNA-21: Elevated levels in patients with metastatic hormone-refractory prostate cancer and potential predictive factor for the efficacy of docetaxel-based chemotherapy. Prostate 2011, 71, 326-331. [CrossRef] [PubMed]

204. Hsu, C.M.; Lin, P.M.; Wang, Y.M.; Chen, Z.J.; Lin, S.F.; Yang, M.Y. Circulating miRNA is a novel marker for head and neck squamous cell carcinoma. Tumour Biol. 2012, 33, 1933-1942. [CrossRef] [PubMed]

205. Tsujiura, M.; Ichikawa, D.; Komatsu, S.; Shiozaki, A.; Takeshita, H.; Kosuga, T.; Konishi, H.; Morimura, R.; Deguchi, K.; Fujiwara, H.; et al. Circulating microRNAs in plasma of patients with gastric cancers. Br. J. Cancer 2010, 102, 1174-1179. [CrossRef] [PubMed]

206. Wang, Z.X.; Bian, H.B.; Wang, J.R.; Cheng, Z.X.; Wang, K.M.; De, W. Prognostic significance of serum miRNA-21 expression in human non-small cell lung cancer. J. Surg. Oncol. 2011, 104, 847-851. [CrossRef] [PubMed]

207. Kanaan, Z.; Rai, S.N.; Eichenberger, M.R.; Roberts, H.; Keskey, B.; Pan, J.; Galandiuk, S. Plasma miR-21: A potential diagnostic marker of colorectal cancer. Ann. Surg. 2012, 256, 544-551. [CrossRef] [PubMed]

208. Burroughs, V.J.; Maxey, R.W.; Levy, R.A. Racial and ethnic differences in response to medicines: Towards individualized pharmaceutical treatment. J. Natl. Med. Assoc. 2002, 94, 1-26. [PubMed]

209. Chapman, M.H.; Tidswell, R.; Dooley, J.S.; Sandanayake, N.S.; Cerec, V.; Deheragoda, M.; Lee, A.J.; Swanton, C.; Andreola, F.; Pereira, S.P. Whole genome rna expression profiling of endoscopic biliary brushings provides data suitable for biomarker discovery in cholangiocarcinoma. J. Hepatol. 2012, 56, 877-885. [CrossRef] [PubMed]

210. Yang, S.; Wu, Y.; Wang, D.; Huang, S.; Wen, Y.; Cao, J.; Zhang, L. Establishment of an experimental method for detecting circulating miRNAs in BDL mice. Clin Exp. Med. 2011, 12, 273-277. [CrossRef] [PubMed]

211. Iorio, M.V.; Croce, C.M. MicroRNA dysregulation in cancer: Diagnostics, monitoring and therapeutics. A comprehensive review. EMBO Mol. Med. 2012, 4, 143-159. [CrossRef] [PubMed]

212. Weber, J.A.; Baxter, D.H.; Zhang, S.; Huang, D.Y.; Huang, K.H.; Lee, M.J.; Galas, D.J.; Wang, K. The microRNA spectrum in 12 body fluids. Clin. Chem. 2010, 56, 1733-1741. [CrossRef] [PubMed] 